\title{
Synthesis, molecular docking and biological evaluation of bis-pyrimidine Schiff base derivatives
}

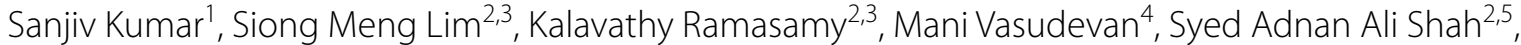 \\ Manikandan Selvaraj ${ }^{6}$ and Balasubramanian Narasimhan ${ }^{1 *}$
}

\begin{abstract}
Background: Heterocyclic pyrimidine nucleus, which is an essential base component of the genetic material of deoxyribonucleic acid, demonstrated various biological activities. A series of bis-pyrimidine Schiff bases were synthesized and screened for its antimicrobial and anticancer potentials. The molecular docking study was carried to find the interaction between active molecules with receptor.

Results: The structures of synthesized bis-pyrimidine Schiff bases were confirmed by spectral studies. The synthesized bis-pyrimidine derivatives were evaluated for their antimicrobial activity ( $\mathrm{MIC}=\mu \mathrm{mol} / \mathrm{mL}$ ) against selected Gram positive; Gram negative bacterial and fungal strains by tube dilution method. The anticancer activity $\left(\mathrm{IC}_{50}=\mu \mathrm{mol} /\right.$ $\mathrm{mL}$ ) of the synthesized compounds was determined against human colorectal carcinoma (HCT116) cancer cell line by Sulforhodamine B (SRB) assay. Molecular docking studies provided information regarding the binding mode of active bis-pyrimidine Schiff bases with the cyclin-dependent kinase 8 (CDK8) receptor.

Conclusions: The antimicrobial screening results indicated that compounds, $\mathbf{q} \mathbf{1}\left(\mathrm{MIC}_{\mathrm{bs}}=0.83 \mu \mathrm{mol} / \mathrm{mL}\right), \mathbf{q} \mathbf{1 6}$ $\left(\mathrm{MIC}_{\mathrm{an}}=1.54 \mu \mathrm{mol} / \mathrm{mL}\right.$ and $\left.\mathrm{MIC}_{\mathrm{ec}}=0.77 \mu \mathrm{mol} / \mathrm{mL}\right), \mathbf{q} \mathbf{1}$ and $\mathbf{q} \mathbf{1 9}\left(\mathrm{MIC}_{\mathrm{ca}}=0.41 \mu \mathrm{mol} / \mathrm{mL}\right)$ and $\mathbf{q 2 0}(\mathrm{MIC}=0.36 \mu \mathrm{mol} /$ $\mathrm{mL})$ are the most active ones. Compounds $\mathbf{q} \mathbf{1}\left(\mathrm{IC}_{50}=0.18 \mu \mathrm{mol} / \mathrm{mL}\right)$ have emerged as potent anticancer molecule against human colorectal carcinoma cancer cell line than the reference drug, 5 -fluorouracil. Molecular docking studies indicated that compound $\mathbf{q} \mathbf{1}$ (the most active molecule) has the maximum hydrogen bond interaction (four) and $\pi-\pi$ stacking (three) network among the bis-pyrimidine Schiff bases.
\end{abstract}

Keywords: Bis-pyrimidine Schiff bases, Antimicrobial, Anticancer, Molecular docking

\section{Background}

Development of novel antimicrobial molecules may provide additional options for the treatment of various microbial infections which affects millions of people worldwide. Cancer is one of the most serious health problems all over the world and one of the leading causes of death, so there is an urgent ongoing need for discovery a highly effective new molecule for cancer treatment with fewer side effects. Heterocyclic pyrimidine nucleus, which is an essential base component of the genetic

\footnotetext{
*Correspondence: naru2000us@yahoo.com

${ }^{1}$ Faculty of Pharmaceutical Sciences, Maharshi Dayanand University, Rohtak 124001, India

Full list of author information is available at the end of the article
}

material of deoxyribonucleic acid, demonstrated various biological activities viz. antimicrobial [1], anticancer [2], antiviral [3], anti-inflammatory [4], antifungal [5], analgesic [6], anticonvulsant [7], antioxidant [8], antitubercular, antimalarial [9] and antileishmanial [10] etc.

Molecular docking technique is routinely used in modern drug discovery for understanding the drug-receptor interaction. This technique has frequently been used to predict the binding affinity and orientation of small drug molecules at the target site. The two aims of docking studies are accurate structural modelling and correct prediction of activity. Macromolecular docking studies provides the most detailed possible view of drug-receptor interaction and has created a new rational approach 
to drug design, where the structure of drug is designed based on its fit to 3D structures of a receptor site [11]. Some marketed drugs contains pyrimidine moiety presented in Fig. 1.

Literature reports reveal that $-\mathrm{NH}_{2}$ group at the 2nd position of pyrimidine enhanced the antimicrobial potential [I] of pyrimidines [12]. $p$-Methoxyphenyl nucleus at 6th position on pyrimidine nucleus [13] showed antimicrobial activity [II]. The $\mathrm{Ar}-\mathrm{Br}$ group on 4th position of pyrimidine nucleus [III] improved the antimicrobial potential [14], $p$-dimethyl amino phenyl nucleus [IV] attached on the pyrimidine nucleus improved the anticancer potential against HCT-116 cell line [15], $p$-chloro and $p$-nitrobenzylideneamino at the 5 th position of pyrimidine ring $[\mathbf{V}-\mathbf{V I}]$ improved the anticancer potential of pyrimidine [16]. The aforementioned findings are summarized in Fig. 2.

Prompted by aforementioned facts, in the present work we have planned to synthesize bis-pyrimidine Schiff bases of 4,4'-(6,6'-(1,4-phenylene)bis(2-aminopyrimidine-6,4-diyl)) diphenol and evaluate their antimicrobial and anticancer potentials along with molecular docking studies.

\section{Results and discussion \\ Chemistry}

The synthetic work is based on Claisen-Schmidt condensation (Scheme 1). Initially, the bis-chalcone was synthesized by the reaction of 1-(4-hydroxyphenyl)ethanone and terephthalaldehyde. The cyclization of bis-chalcone (intermediate-I) to yield bis-pyrimidine (intermediate-II) was effected with guanidine hydrochloride. The reaction of bis-pyrimidine (intermediate-II) with corresponding substituted aldehyde resulted in the formation of title compounds (q1-q20). The poor \% yield of some of the synthesized compounds may be attributed to any one or more of the following reasons: (1) The reaction may be reversible and position of equilibrium is unfavorable to the product; (2) The incursion of side reactions leading to the formation of by-products; (3) The premature work-up of the reaction before its completion; (4) The<smiles>COc1cc(Cc2cnc(N)nc2N)c2c(c1OC)OC(C1CC1)C=C2</smiles>

(Dihydrofolate inhibitor)<smiles>Cc1cn(C2CCC(CO)O2)c(=O)nc1N</smiles>

Zalcitabine

(Antiviral)<smiles>Cc1ccc(C(=O)Nc2cc(-n3cncc3C)cc(C(F)(F)F)c2)cc1Nc1nccc(-c2ccncc2)n1</smiles>

Nilotinib

(Anticancer)<smiles>COc1cc(NS(=O)(=O)c2ccc(N)cc2)nc(C)n1</smiles>

Sulfamethomidine

(Antibacterial)<smiles>CC(c1ncncc1F)[C@@](O)(Cn1cncn1)c1ccc(F)cc1F</smiles>

Voriconazole

(Antifungal)<smiles>CCCCCOC(=O)Nc1nc(=O)n(C2OC(C)C(O)C2O)cc1F</smiles>

Capecitabine

(Anticancer)

Fig. 1 Marketed preparations of pyrimidine molecules 


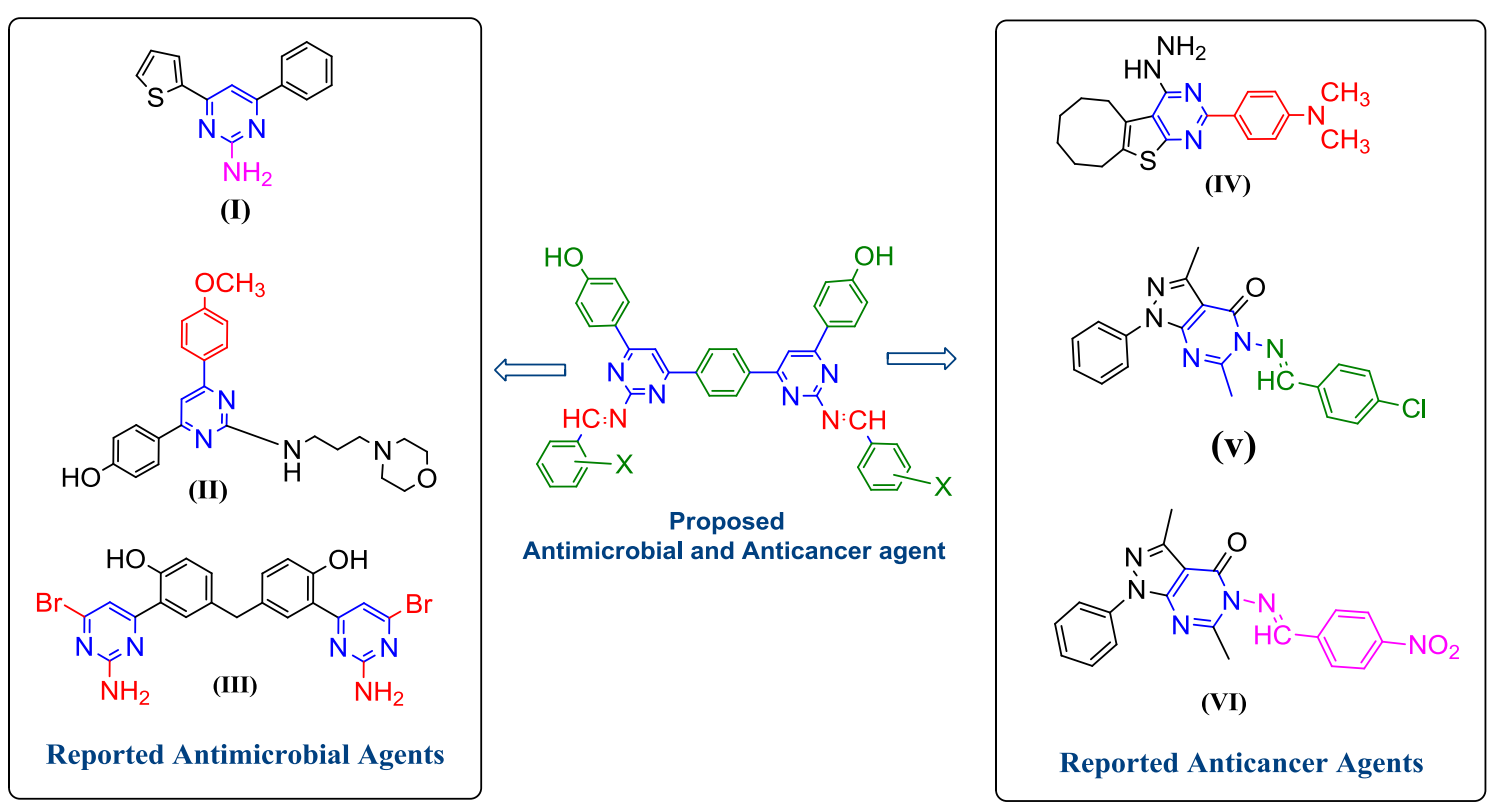

Fig. 2 Design of heterocyclic bis-pyrimidine derivatives for antimicrobial and anticancer activity based on literature

volatilization of products during reaction or work-up; (5) The loss of product due to incomplete extraction, inefficient crystallization or other work-up procedures; (6) The presence of contaminants in the reactants or reagents leading to a less efficient reaction [17]. The synthesized compounds were characterized by the determination of their physicochemical and spectral characteristics. The chemical structures of the synthesized bis-pyrimidine Schiff bases (q1-q20) were established by ${ }^{1} \mathrm{H} /{ }^{13} \mathrm{C}-\mathrm{NMR}$, FT-IR, mass spectral studies and elemental analysis. The IR spectrum of bis-chalcone (I) showed the characteristic band at $1693 \mathrm{~cm}^{-1}$ which indicated the presence of a $-\mathrm{C}=\mathrm{O}$ group and characteristic bands at 3088 and $1427 \mathrm{~cm}^{-1}$ for the presence of $\mathrm{C}-\mathrm{H}$ and $\mathrm{C}=\mathrm{C}$ group in aromatic ring, respectively. The existence of $\mathrm{Ar}-\mathrm{OH}$ group in bis-chalcone (I) was displayed by the existence Ar-OH stretches in the scale of $3363 \mathrm{~cm}^{-1}$ and characteristic bands at 2864 and $1497 \mathrm{~cm}^{-1}$ indicated the presence of $\mathrm{C}-\mathrm{H}$ and $\mathrm{C}=\mathrm{C}$ group in alkyl chain, respectively. Bis-pyrimidine (II) showed the characteristic IR bands at 3058 and $1537 \mathrm{~cm}^{-1}$ for the presence of $\mathrm{C}-\mathrm{H}$ and $\mathrm{C}=\mathrm{C}$ group in aromatic ring, respectively and characteristic bands at 3331 and $1604 \mathrm{~cm}^{-1}$ for the presence of $-\mathrm{NH}_{2}$ and $\mathrm{N}=\mathrm{CH}$ str. The structure of the bis-chalcone and its cyclized products were further confirmed by the corresponding ${ }^{1} \mathrm{H}$-NMR spectra. The ${ }^{1} \mathrm{H}-\mathrm{NMR}$ spectrum of bis-chalcone I showed two doublets at $7.59 \mathrm{ppm}$ $(J=15.1 \mathrm{~Hz})$ and $8.06 \mathrm{ppm}(J=15.1 \mathrm{~Hz})$ indicating that the $\mathrm{CH}=\mathrm{CH}$ group in the enone linkage is in a transconformation. The ${ }^{1} \mathrm{H}$-NMR spectrum of intermediate-II showed a multiplet signals between 7.65 and $8.26 \delta \mathrm{ppm}$ confirming the cyclisation of the bis-chalcone to give bis-pyrimidine ring. The ${ }^{1} \mathrm{H}-\mathrm{NMR}$ spectrum of compound intermediate-II showed a sharp singlet at $7.26 \delta$ ppm due to the $\mathrm{NH}_{2}$ protons and it also showed a sharp singlet at $7.60 \delta \mathrm{ppm}$ due to $\mathrm{HC}=\mathrm{C}$ group, which confirmed the cyclization of the bis-chalcone into a bispyrimidine ring. The impression of IR absorption band at $3387-2237 \mathrm{~cm}^{-1}$ in the spectral data of synthesized derivatives (q1-q20) displayed the presence of $\mathrm{Ar}-\mathrm{OH}$ category on the aromatic nucleus substituted at the ortho, meta and para-position of the synthesized derivatives. The IR absorption band in the scale of $690-515 \mathrm{~cm}^{-1}$ corresponds to the $\mathrm{C}-\mathrm{Br}$ stretching of aromatic-bromo derivatives (q14, q15 and q16). The existence of $\mathrm{Ar}-$ $\mathrm{NO}_{2}$ category in derivatives $\mathbf{q 3}, \mathbf{q 7}$ and $\mathbf{q 1 8}$ was displayed by the existence of symmetric and asymmetric $\mathrm{Ar}-\mathrm{NO}_{2}$ stretches in the scale of $1365-1335$ and $1550-1510 \mathrm{~cm}^{-1}$ respectively. The existence of an arylalkyl ether category $\left(\mathrm{Ar}-\mathrm{OCH}_{3}\right)$ in derivatives, $\mathbf{q 2}, \mathbf{q 4}$, q10, q13 and q20 are established by the existence of an IR absorption band around $3150-3050 \mathrm{~cm}^{-1}$. Further, the existence of halogen group in compounds $\mathbf{q 5}$ and $\mathbf{q 1 7}$ is indicated by the existence of $\mathrm{Ar}-\mathrm{Cl}$ stretching vibrations at $600-800 \mathrm{~cm}^{-1}$. The impression of IR stretching vibration at $3100-3000$ and $1580-1600 \mathrm{~cm}^{-1}$ in the spectral data of synthesized derivatives $(\mathbf{q 1}-\mathbf{q 2 0})$ specified the existence of $\mathrm{C}-\mathrm{H}$ and $\mathrm{C}=\mathrm{C}$ group, respectively. The appearance of IR stretching $1604-1700 \mathrm{~cm}^{-1}$ in the spectral data of synthesized derivatives $(\mathbf{q 1}-\mathbf{q} 20)$ 


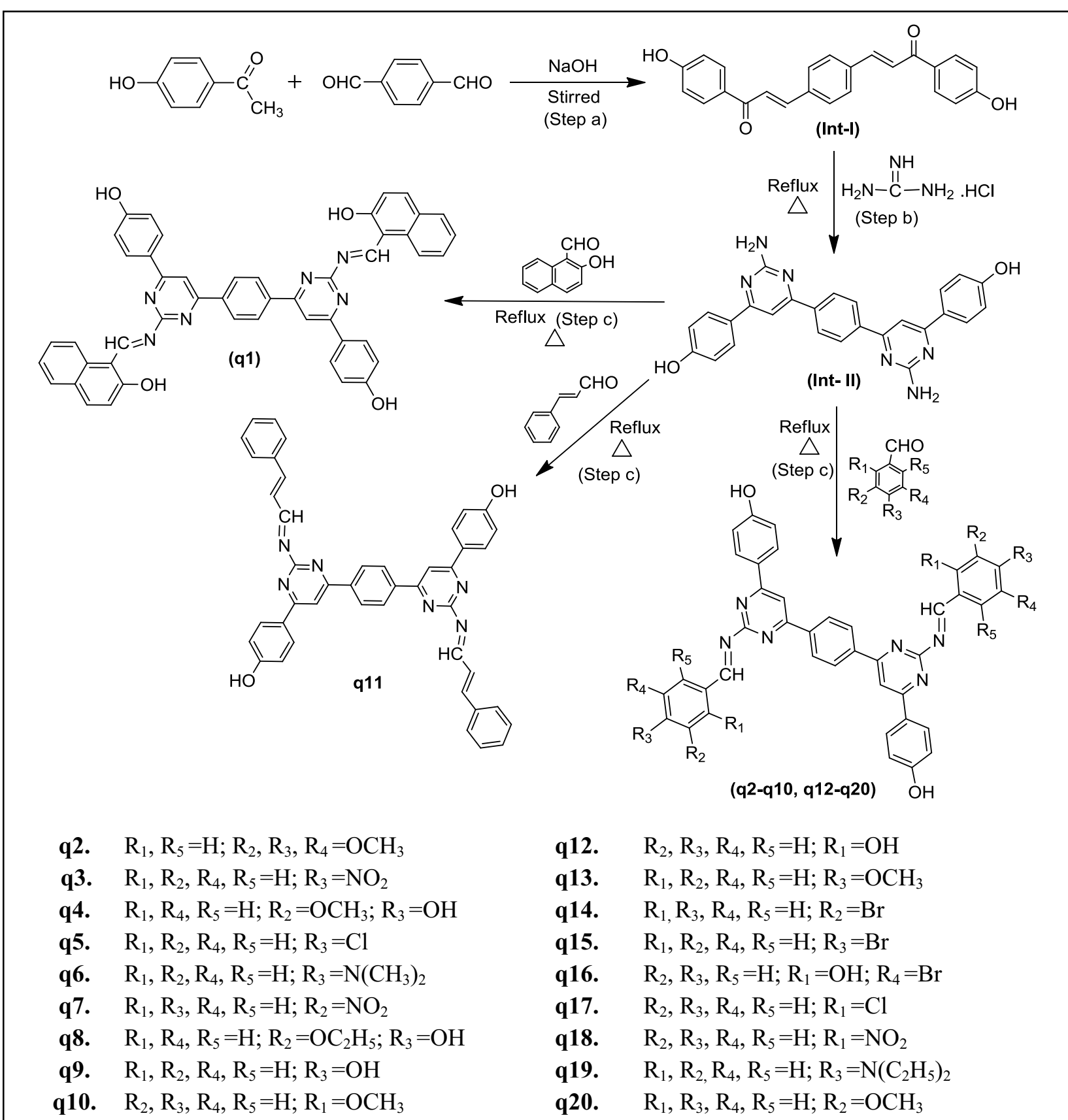

\section{Reaction condition:}

Step a: Terephthalaldehyde, $\mathrm{NaOH}$, Methanol, Stirred 2-3 h, at room temp; Step b: Guanidine hydrochloride, Methanol, HCl, Reflux 5-6 h $\left(60^{\circ} \mathrm{C}\right)$; Step c: Substituted aldehyde, Methanol, Reflux 3-4 h $\left(40^{\circ} \mathrm{C}\right)$ 
specified the existence of $\mathrm{N}=\mathrm{CH}$ group. The impression of IR stretching at $1630 \mathrm{~cm}^{-1}$ in the spectra of intermediate specified the existence of $\mathrm{C}=\mathrm{O}$ group. The multiplet signals between 6.75 and $8.22 \delta \mathrm{ppm}$ in ${ }^{1} \mathrm{H}-\mathrm{NMR}$ spectra is indicative of aromatic proton of synthesized derivatives. The compounds, q2, q4, q10, q13 and q20 showed singlet at 3.71-3.82 $\delta \mathrm{ppm}$ due to the existence of $\mathrm{OCH}_{3}$ of $\mathrm{Ar}-\mathrm{OCH}_{3}$. All compounds showed singlet at $7.51-8.43 \delta \mathrm{ppm}$ due to the existence of $\mathrm{N}=\mathrm{CH}$ in pyrimidine ring. Compounds showed singlet at 7.70$7.74 \delta \mathrm{ppm}$ due to the existence of $-\mathrm{CH}$ in pyrimidine ring. Compound $\mathbf{q 6}$ showed singlet at $2.89 \delta \mathrm{ppm}$ due to existence of $-\mathrm{N}\left(\mathrm{CH}_{3}\right)_{2}$ at the para position. The compound $\mathbf{q 1 9}$ showed quadrate at $3.41 \delta \mathrm{ppm}$ and triplet at $1.13 \delta \mathrm{ppm}$ due to presence of $-\mathrm{N}\left(\mathrm{C}_{2} \mathrm{H}_{5}\right)_{2}$ at para position. The elemental analysis studies of the synthesized bis-pyrimidine Schiff bases were found within $\pm 0.4 \%$ of the theoretical results. Finally, the ${ }^{13} \mathrm{C}$-NMR spectra of the bis-chalcone and the cyclized bis-pyrimidine were recorded in DMSO- $d_{6}$ and the spectral signals were in good agreement with the proposed molecular structure of the synthesized compounds. ${ }^{13} \mathrm{C}$-NMR spectral interpretation details synthesized compounds are given in the experimental section.

\section{In vitro antimicrobial activity}

Antimicrobial screening of synthesized derivatives against Gram +ve bacterial species: Staphylococcus aureus, Bacillus subtilis, the Gram -ve bacterium Escherichia coli and fungal species: Aspergillus niger and Candida albicans was done by tube dilution technique. Antimicrobial activity results indicated (Table 1) particularly; compounds q1, q16, q19 and q20 have shown more promising antimicrobial activity

Table 1 Antimicrobial and anticancer activities of synthesized bis-pyrimidine Schiff bases

\begin{tabular}{|c|c|c|c|c|c|c|}
\hline \multirow[t]{4}{*}{ Compounds } & \multicolumn{5}{|c|}{ Minimum inhibitory concentration $(\mathrm{MIC}=\mu \mathrm{mol} / \mathrm{mL}$ ) } & \multirow{4}{*}{$\begin{array}{l}\mathrm{IC}_{50}=\mu \mathrm{mol} / \mathrm{mL} \\
\text { (HCT116) cancer } \\
\text { cell line }\end{array}$} \\
\hline & \multicolumn{3}{|l|}{ Bacterial species } & \multicolumn{2}{|l|}{ Fungal species } & \\
\hline & \multicolumn{2}{|l|}{ Gram positive } & \multirow{2}{*}{$\begin{array}{l}\text { Gram negative } \\
\text { E. coli (MTCC 443) }\end{array}$} & \multirow{2}{*}{$\begin{array}{l}\text { C. albicans (MTCC } \\
\text { 227) }\end{array}$} & \multirow[t]{2}{*}{ A. niger (MTCC 281) } & \\
\hline & $\begin{array}{l}\text { B. subtilis (MTCC } \\
441 \text { ) }\end{array}$ & $\begin{array}{l}\text { S. aureus (MTCC } \\
3160 \text { ) }\end{array}$ & & & & \\
\hline $\mathbf{q 1}$ & 0.83 & 0.83 & 1.65 & 0.41 & 1.65 & 0.18 \\
\hline $\mathbf{q 2}$ & 1.55 & 1.55 & 1.55 & 0.78 & 1.55 & 3.73 \\
\hline q3 & 1.75 & 1.75 & 1.75 & 0.87 & 1.75 & 3.64 \\
\hline q4 & 1.74 & 1.74 & 1.74 & 0.87 & 1.74 & 5.02 \\
\hline q5 & 1.80 & 1.80 & 1.80 & 0.90 & 1.80 & 2.31 \\
\hline q6 & 1.76 & 1.76 & 1.76 & 0.88 & 1.76 & 3.38 \\
\hline q7 & 1.75 & 1.75 & 1.75 & 0.87 & 1.75 & 5.59 \\
\hline q8 & 1.68 & 1.68 & 1.68 & 0.84 & 1.68 & 2.68 \\
\hline q9 & 1.90 & 1.90 & 1.90 & 1.90 & 1.90 & 7.61 \\
\hline q10 & 1.82 & 1.82 & 1.82 & 0.91 & 1.82 & $>14.60$ \\
\hline$q 11$ & 1.85 & 1.85 & 1.85 & 0.92 & 1.85 & 6.79 \\
\hline$q 12$ & 1.90 & 1.90 & 1.90 & 0.95 & 1.90 & 7.00 \\
\hline q13 & 1.82 & 1.82 & 1.82 & 0.46 & 1.82 & 2.92 \\
\hline q14 & 1.60 & 1.60 & 1.60 & 0.80 & 1.60 & 7.16 \\
\hline q15 & 1.60 & 1.60 & 1.60 & 1.60 & 1.60 & $>12.79$ \\
\hline q16 & 1.54 & 1.54 & 0.77 & 0.77 & 1.54 & 11.06 \\
\hline$q 17$ & 1.80 & 1.80 & 1.80 & 0.45 & 1.80 & 10.09 \\
\hline q18 & 1.75 & 1.75 & 0.87 & 0.44 & 1.75 & 9.79 \\
\hline q19 & 1.63 & 1.63 & 0.81 & 0.41 & 1.63 & 11.73 \\
\hline q20 & 1.82 & 0.36 & 1.82 & 0.91 & 1.82 & $>14.60$ \\
\hline DMSO & 0.00 & 0.00 & 0.00 & 0.00 & 0.00 & - \\
\hline Norfloxacin & 0.47 & 0.47 & 0.47 & - & - & - \\
\hline Fluconazole & - & - & - & 0.50 & 0.50 & - \\
\hline 5-Fluorouracil & - & - & - & - & - & 0.35 \\
\hline
\end{tabular}

Std. drugs norfloxacin-antibacterial; fluconazole-antifungal; 5-fluorouracil-anticancer 
as compared to standard drugs norfloxacin (antibacterial) and fluconazole (antifungal) while other derivatives are moderately active. In the case of Gram +ve antibacterial study, compound $\mathbf{q 1}$ was found to be most potent one against $B$. subtilis with MIC value of $0.83 \mu \mathrm{mol} / \mathrm{mL}$ and compound $\mathbf{q 2 0}$ showed significant activity against $S$. aureus with MIC value of $0.36 \mu \mathrm{mol} /$ $\mathrm{mL}$. In the case of Gram - ve bacterial study, compound $\mathbf{q 1 6}$ displayed appreciable antibacterial activity against $E$. coli. The antifungal activity results indicated that compounds $\mathbf{q 1}$ and $\mathbf{q} 19\left(\mathrm{MIC}_{c a}=0.41 \mu \mathrm{mol} / \mathrm{mL}\right)$ and compound q16 $\left(\mathrm{MIC}_{a n}=1.54 \mu \mathrm{mol} / \mathrm{mL}\right)$ were found to be most effective ones against $C$. albicans and $A$. niger, respectively. The most active synthesized bispyrimidine Schiff base derivatives q19 and $\mathbf{q 2 0}$ may be taken as lead compounds to discover novel antimicrobial agent.

\section{In vitro anticancer activity}

The in vitro anticancer activity of synthesized bispyrimidine derivatives was carried out against human colorectal cancer cell line (HCT-116 (ATCC CCL-247) and the results are presented in Table 1. Anticancer screening results revealed that in general bis-pyrimidine Schiff bases exhibited good anticancer potential against human colorectal cancer cell line, especially, compounds $\mathbf{q 1}\left(\mathrm{IC}_{50}=0.18 \mu \mathrm{mol} / \mathrm{mL}\right)$ displayed anticancer activity more than the reference drug 5 -fluorouracil $\left(\mathrm{IC}_{50}=0.35 \mu \mathrm{mol} / \mathrm{L}\right)$.

\section{Structure-activity relationship}

From the antimicrobial and anticancer results, the structure-activity relationship of synthesized bis-pyrimidine Schiff bases (SAR, Fig. 3) can be deduced as follows:

1. Compound q1 (synthesized using 2-OH naphthaldehyde) was found to be most potent antimicrobial agent against $B$. subtilis and C. albicans as well anticancer potential against HCT-116 (ATCC CCL247) cancer cell line. From the molecular docking studies, compound $\mathbf{q} \mathbf{1}$ being the most active molecule has the maximum hydrogen bond interaction (four) and $\pi-\pi$ stacking (three) network among the bis-pyrimidine Schiff bases.

2. Electron withdrawing group $\left[-\mathrm{N}\left(\mathrm{C}_{2} \mathrm{H}_{5}\right)_{2}\right]$ on benzylidene portion of compound $\mathbf{q 1 9}$ increased the antifungal potential against $C$. albicans.

3. Presence of electron releasing group $\left(-\mathrm{OCH}_{3}\right)$ on benzylidene portion of compound q20 enhanced the antibacterial potential against $S$. aureus.

4. Compound q16 (synthesized using 5-bromo-2-hydroxy benzaldehyde) improved the antimicrobial potential against $A$. niger and $E$. coli.

From the aforementioned results, we may conclude that different structural requirements are required for a compound to be effective against different targets. The aforementioned facts are supported by the earlier research findings $[18,19]$.

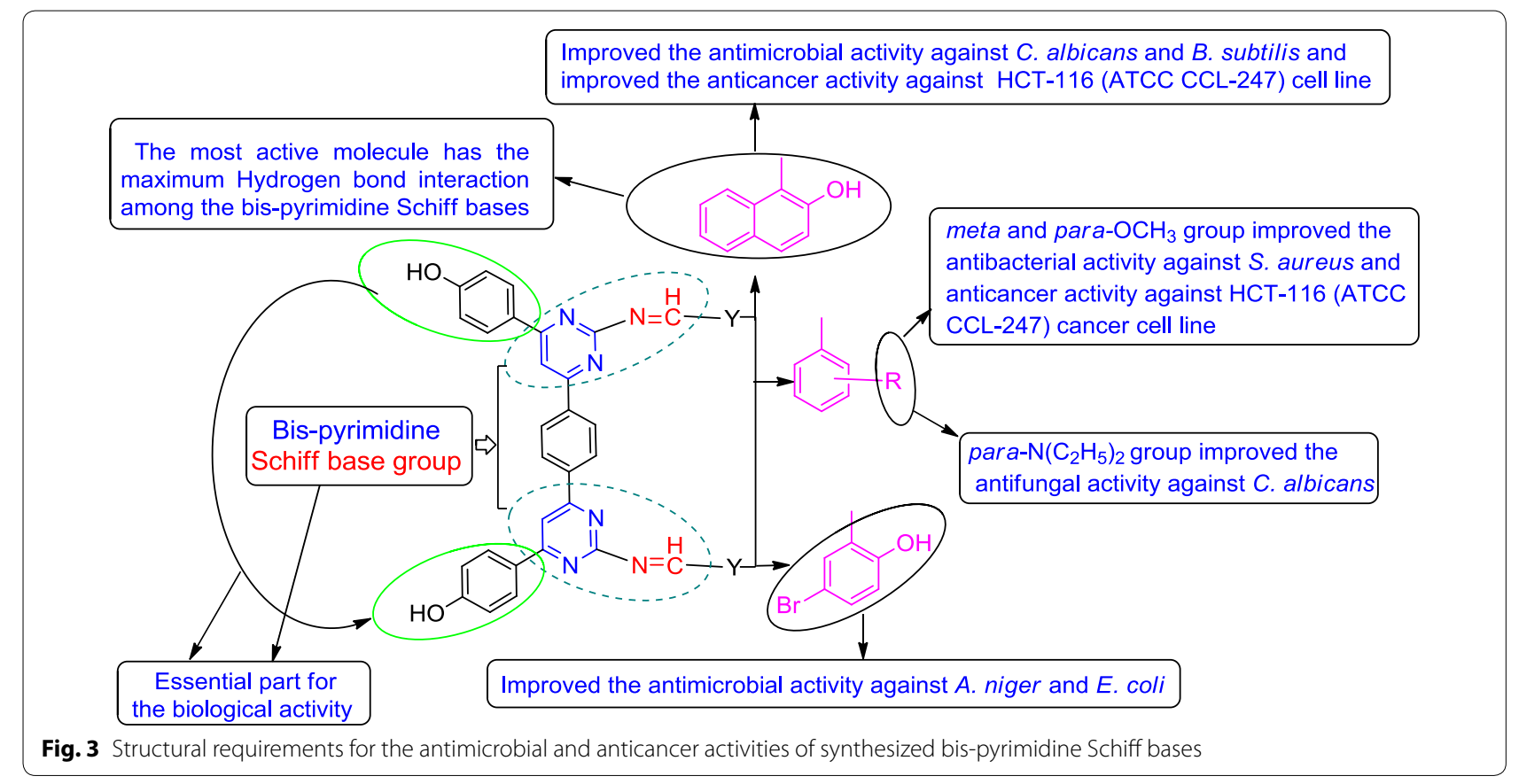




\section{Docking studies and binding mode analysis}

Molecular modeling studies were accomplished to investigate the possible binding mode of the synthesized twenty bis-pyrimidine Schiff base derivatives targeting the crystal structure of cyclin-dependent kinase 8 using GOLD docking program. The Schiff bases were docked into the active site of cyclin-dependent kinase CDK8, using co-complex 5XG ligand as the reference with $12 \mathrm{~A}$ radius. The results were analyzed based on the ChemPLP scoring function obtained from GOLD. The docked binding mode was analyzed for the interactions between specific compounds and CDK8. Figure 4a shows the binding mode of the active four compounds into the active site of CDK8. While in Fig. 4b shows the binding mode of the co-complexed ligand 5XG and 5-fluorouracil (the standard inhibitor of cancer) is having a different binding mode to that of the four active compounds of bis-pyrimidine Schiff bases. In-depth analysis of the interaction pattern for the most active compounds, q1, q5, q8 and q13 are discussed in the following section.

The binding mode of the compound $\mathbf{q} 1$ positioned in the gorge of the CDK8 active site shows that one of the naphthalenol $\mathrm{OH}$ of compound $\mathbf{q} \mathbf{1}$ forms hydrogen bond with Glu66 side chain oxygen and with $\mathrm{NH}$ of Lys52 side chain, respectively. Additionally, the side chain $\mathrm{NH}$ of Lys52 also hydrogen bond with pyrimidinyl nitrogen. While the one of the hydroxyphenyl $\mathrm{OH}$ of compound q1 form a hydrogen bond with side chain oxygen and backbone HN of Glu357. While the Tyr32 phenyl ring forms $\pi-\pi$ stacking with phenyl and pyrimidinyl ring of compound $\mathbf{q} \mathbf{1}$ and one of the naphthalene ring also form $\pi-\pi$ stacking with indole ring of Trp105. Besides a pool of hydrophobic interaction between compound $\mathbf{q 1}$ and Phe97, Leu70, Ala172, Ile79, Leu158, Met174, Phe176,
Ile54, Val35, Val27, Leu359 and Ala155 also stabilize the interaction (Fig. 5a). Compound $\mathbf{1}$ being the most active compound has the maximum hydrogen bond interaction (four) and $\pi-\pi$ stacking (three) network among the bis-pyrimidine Schiff base derivatives. Figure $5 \mathrm{~b}$ shows the docking orientation of compound $\mathbf{q 5}$, which is stabilized by the hydrogen bond interaction between one of the hydroxyphenyl $\mathrm{OH}$ of compound $\mathbf{q} 5$ forms hydrogen bond with side chain oxygen and backbone $\mathrm{HN}$ of Glu357. While the other hydroxyphenyl $\mathrm{OH}$ forms hydrogen bond with backbone oxygen of Ile79. Meanwhile, $\pi-\pi$ stacking between hydroxyphenyl ring and imidazole ring of His 106, and between chlorophenyl ring and indole ring of Trp105, and $\pi-\pi$ stacking between pyrimidinyl ring of compound $\mathbf{q 5}$ and Tyr32 phenyl ring is observed. Additionally hydrophobic contact between compound q5 and residues such as Val27, Val35, Ala172, Phe97, Leu70, Ile171, Ile79, Val78, Met174, Phe176, Ile54, Leu359 and Ala155 stabilize the complex. While in the case of compound $\mathbf{q 5}$, is the second most active compound with two hydrogen bond interactions and three $\pi-\pi$ stacking network.

In compound $\mathbf{q 8}$, hydrogen bond interaction between the side chain $\mathrm{NH}$ of Lys52 forms hydrogen bond with pyrimidinyl nitrogen and the Glu357 side chain oxygen and backbone $\mathrm{HN}$ forms hydrogen bond with hydroxyphenyl $\mathrm{OH}$ of compound q8. Subsequently, $\pi-\pi$ stacking between pyrimidinyl ring of compound $\mathbf{q} 8$ with the Tyr32 phenyl ring and other $\pi-\pi$ stacking between hydroxyphenyl rings of compound $\mathbf{q 8}$ with imidazole ring of His106 is observed. Likewise, the presence of aliphatic ethyl group with aromatic rings of compound $\mathbf{q} 8$ forms hydrophobic contacts with Val27, Val35, Ala172, Phe97, Leu70, Ile79, Leu158, Met174, Ile54, Ala63, Phe176, Ala177,
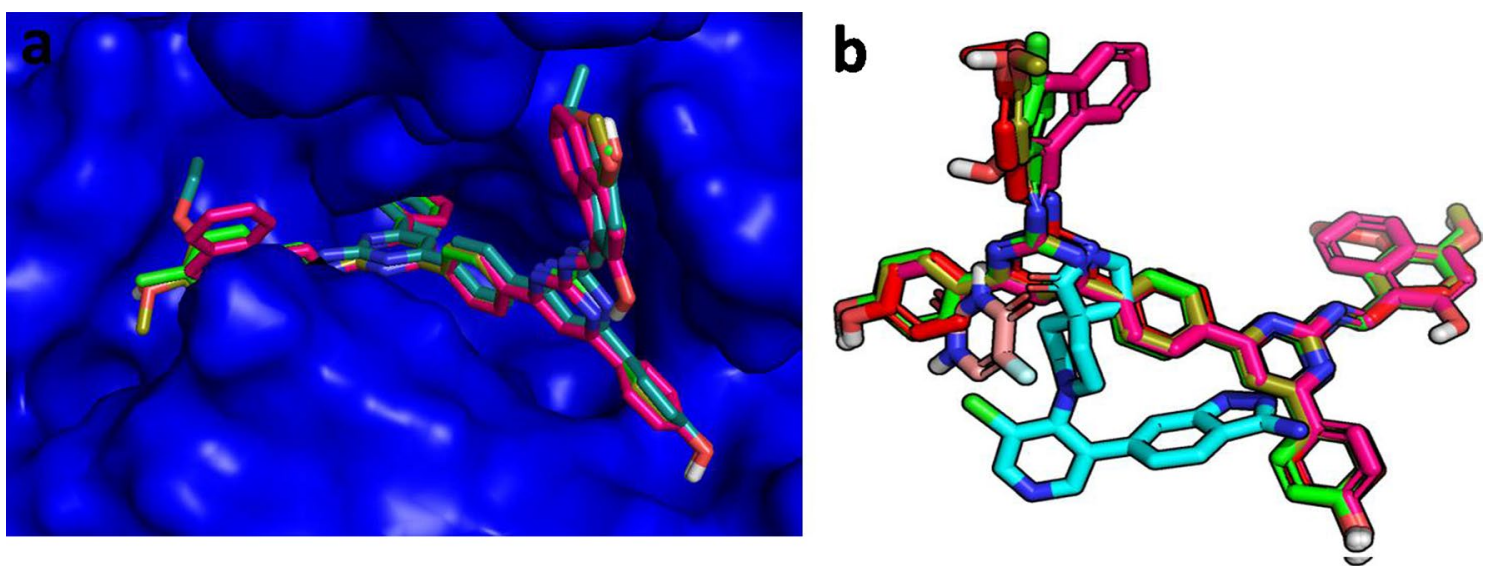

Fig. 4 a Binding mode of four most active compounds into the CDK8 active site. b Overlay of Compound q1 (magenta color), Compound q5 (green color), Compound $\mathbf{q} \mathbf{8}$ (red color) and Compound $\mathbf{q} \mathbf{1 3}$ (split pea color) and PDB Complexed ligand 5XG (color cyan) and 5-Fluorouracil (salmon color) as the reference 


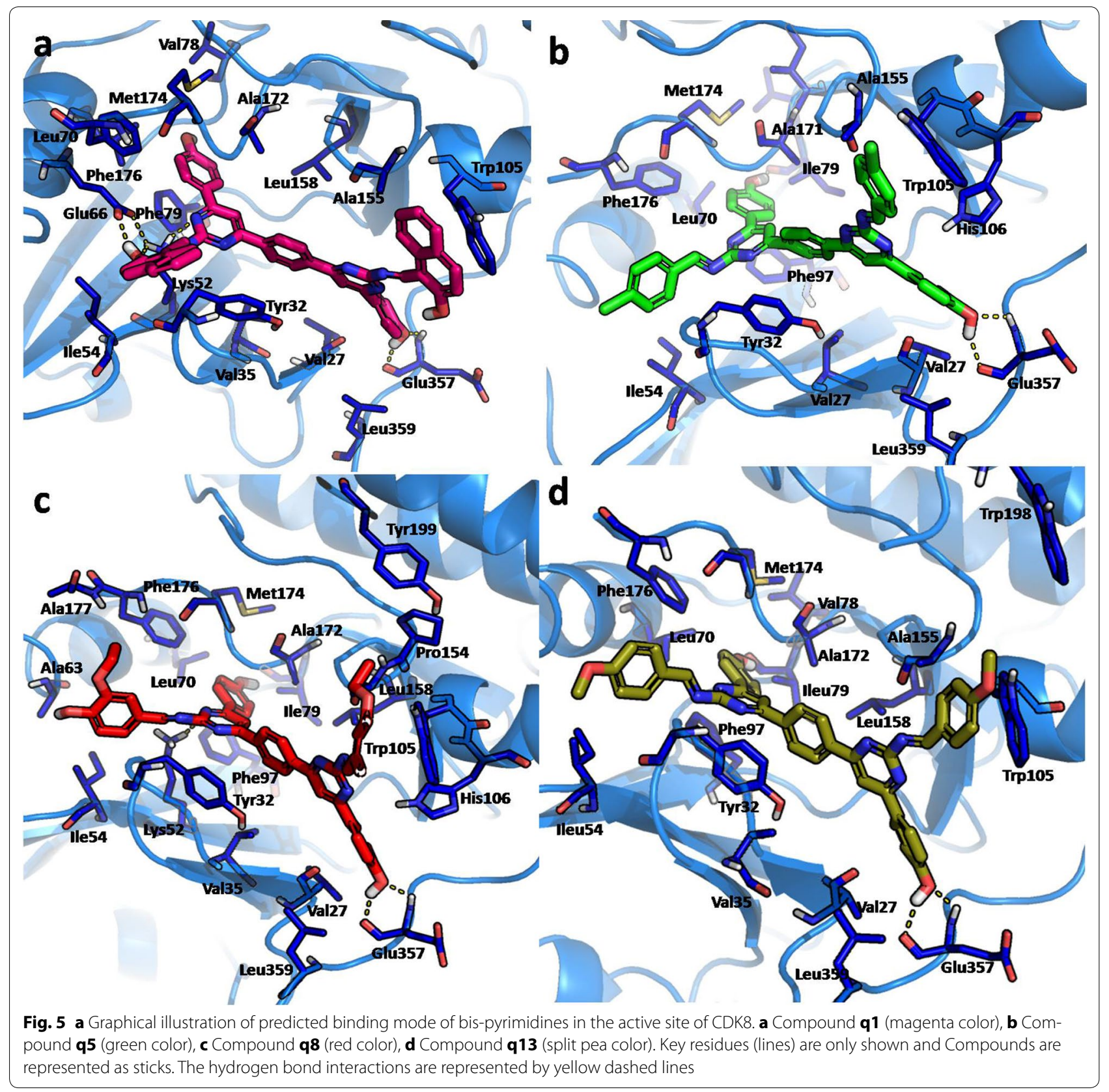

Trp105, Pro154, Ala155, Tyr199 and Leu359 is observed (Fig. 5c). While in the case of compound q8, is the third most active compound with two hydrogen bond interactions and two $\pi-\pi$ stacking interaction.

In the case of compound q13, there is a stable hydrogen bond established between the hydroxyphenyl $\mathrm{OH}$ with the Glu357 side chain oxygen and backbone HN. While there is the presence of $\pi-\pi$ stacking between pyrimidinyl and phenyl ring of compound q13 with the Tyr32 phenyl ring is noticed. The indole ring of Trp105 forms $\pi-\pi$ stacking with the one of the methoxyphenyl ring. Additionally, hydrophobic contact is established between the aromatic groups of compound $\mathbf{q 1 3}$ with the key hydrophobic residues such as Val27, Val35, Ile54, Phe97, Leu158, Val78, Ala172, Leu70, Ile79, Met174, Phe176, Ala155, Trp198, Leu359 that stabilize the complex (Fig. 5d). whereas in the case of compound $\mathbf{q 8}$, is the fourth most active compound with two hydrogen bond interactions and two $\pi-\pi$ stacking interaction. In the activity profile of the inhibitory assay there is no much 
difference among compounds, q5, q8 and q13. Therefore their binding mode interaction is more or less closer to each other. The hydrogen bonding network and the $\pi-\pi$ stacking properties could be the key interactions established by the most active compounds that significantly contribute towards their activity profile. Despite, the fact that the hydrophobic interaction contribution is moderate among the series.

Mutations in adenomatous polyposis coli (APC)/ $\beta$ catenin resulting in an aberrant activation of $\mathrm{Wnt} / \beta$ catenin pathway are common in colorectal cancer $(\mathrm{CRC})$, suggesting that targeting the $\beta$-catenin pathway with chemopreventive/anticancer agents could be a potential translational approach to control CRC. Recent literature revealed that $\beta$-catenin transcriptional activity is positively regulated by the kinase activity of CDK8 and identified it as a CRC oncogene. CDK8, along with cyclin C, Med12, and Med13, forms a "mediator complex" that is involved in the regulation of transcription [20]. The synthesized bispyrimidine Schiff bases may exert their anticancer effect by the inhibition of CDK8 mediated transcription. This was also supported by the observation of Mariaule and Belmont [21] who stated that the pyrimidine is one of the most potential heterocyclic molecules in inhibiting the cyclin dependent kinase as well by the results of molecular docking studies against CDK8 in the current study. Pyrimidines are found to be antagonists of folic acid; hence, a large number of substituted pyrimidines have been synthesized as antifolates and it was eventually proved that these pyrimidines are inhibitors of dihydrofolate reductase (DHFR) [19]. In light of above, the antimicrobial activity of bispyrimidines synthesized in the present study may be attributed to the inhibition of dihydrofolate reductase of the microbe.

\section{Theoretical ADME prediction of twenty bis-pyrimidine Schiff base derivatives}

Theoretical calculations of the ADME (absorption, distribution, metabolism and excretion) properties of synthesized bis-pyrimidine Schiff base derivatives were done using QikPro. Nearly eight physically significant descriptors and pharmacologically relevant properties of the twenty bis-pyrimidine derivatives were predicted and analyzed (Table 2). Aqueous solubility of organic compounds plays a key impact on many ADME associated properties like uptake, distribution, transport, and ultimately bioavailability. The twenty bis-pyrimidine derivatives solubility values were within the range [22]. Finally, the Lipinski's rule of five and Qikprop rule of three were all within the range for the twenty bis-pyrimidine Schiff bases and thus making these derivatives as suitable drug candidates.

\section{Experimental section}

Preparatory materials for the research work were obtained from commercial sources i.e. Loba Chemie, Pvt Ltd. Mumbai, India; Central Drug House (CDH) Pvt. Ltd., New Delhi, India and HiMedia Laboratory Pvt. Ltd., Delhi, India, used without further purification. All reactions were monitored by thin-layer chromatography on $0.25 \mathrm{~mm}$ silica gel (Merck) plates, using benzene as mobile phase and spots were observed by exposure to iodine vapours or visualized with UV light. Melting points of synthesized compounds was determined in open capillary tube. An infrared spectrum was recorded (KBr-pellets) in Bruker 12060280, Software: OPUS 7.2.139.1294 spectrometer. ${ }^{1} \mathrm{H}-\mathrm{NMR}$ and ${ }^{13} \mathrm{C}$ NMR were recorded at 600 and $150 \mathrm{MHz}$, respectively on Bruker Avance III 600 NMR spectrometer by appropriate deuterated solvents. The results are conveyed in parts per million $(\delta, \mathrm{ppm})$ downfield from tetramethyl silane (internal standard). ${ }^{1} \mathrm{H}$-NMR spectral details of the synthesized derivatives are represented with multiplicity like singlet (s); doublet $(\mathrm{d})$; triplet $(\mathrm{t})$; multiplet $(\mathrm{m})$ and the number hydrogen ion. Elemental analysis of the new synthesized compounds was obtained by Perkin-Elmer 2400 $\mathrm{C}, \mathrm{H}$ and $\mathrm{N}$ analyzer. All the compounds gave $\mathrm{C}, \mathrm{H}$ and $\mathrm{N}$ analysis within $\pm 0.4 \%$ of the theoretical results. Mass spectra were taken on Waters Micromass Q-ToF Micro instrument.

\section{General procedure of the synthesized compounds Step a: synthesis of 3,3'-(1,4-phenylene) bis(1-(4-hydroxyphenyl)prop-2-en-1-one (intermediate-l)}

The reaction mixture of 1-(4-hydroxyphenyl)ethanone $(0.02 \mathrm{~mol})$ and terephthalaldehyde $(0.01 \mathrm{~mol})$ were stirred for $2-3 \mathrm{~h}$ in methanol $(5-10 \mathrm{~mL})$ followed by drop wise addition of sodium hydroxide solution $(10 \mathrm{~mL} 40 \%)$ with constant stirring at room temperature till a dark yellow mass was obtained. Then reaction mixture was allowed to stand overnight at room temperature and then poured into icecold water and acidified with hydrochloric acid and the precipitated 3,3'-(1,4-phenylene)bis(1-(4-hydroxyphenyl)prop-2-en-1-one was filtered, dried and recrystallized from methanol [23].

\section{Step b: synthesis of 4,4'-(6,6'-(1,4-phenylene) bis(2-aminopyrimidine-6,4-diyl))diphenol (intermediate-II)} The solution of 3,3'-(1,4-phenylene)bis(1-(4-hydroxyphenyl)prop-2-en-1-one $(0.01 \mathrm{~mol})$ (synthesized in previous step-a) in methanol $(80 \mathrm{~mL})$ was added with $0.01 \mathrm{~mol}$ of potassium hydroxide and $40 \mathrm{~mL}$ of $0.50 \mathrm{M}$ solution of guanidine hydrochloride and refluxed for 5-6 h. The reaction mixture was then cooled and acidified with few drops of hydrochloric acid ( $20 \mathrm{~mL}$ of $0.5 \mathrm{M}$ solution) and the resultant precipitate of $4,4^{\prime}-\left(6,6^{\prime}-(1,4-\right.$ phenylene) 
Table 2 QikProp ADMET Prediction of twenty bis-pyrimidine derivatives

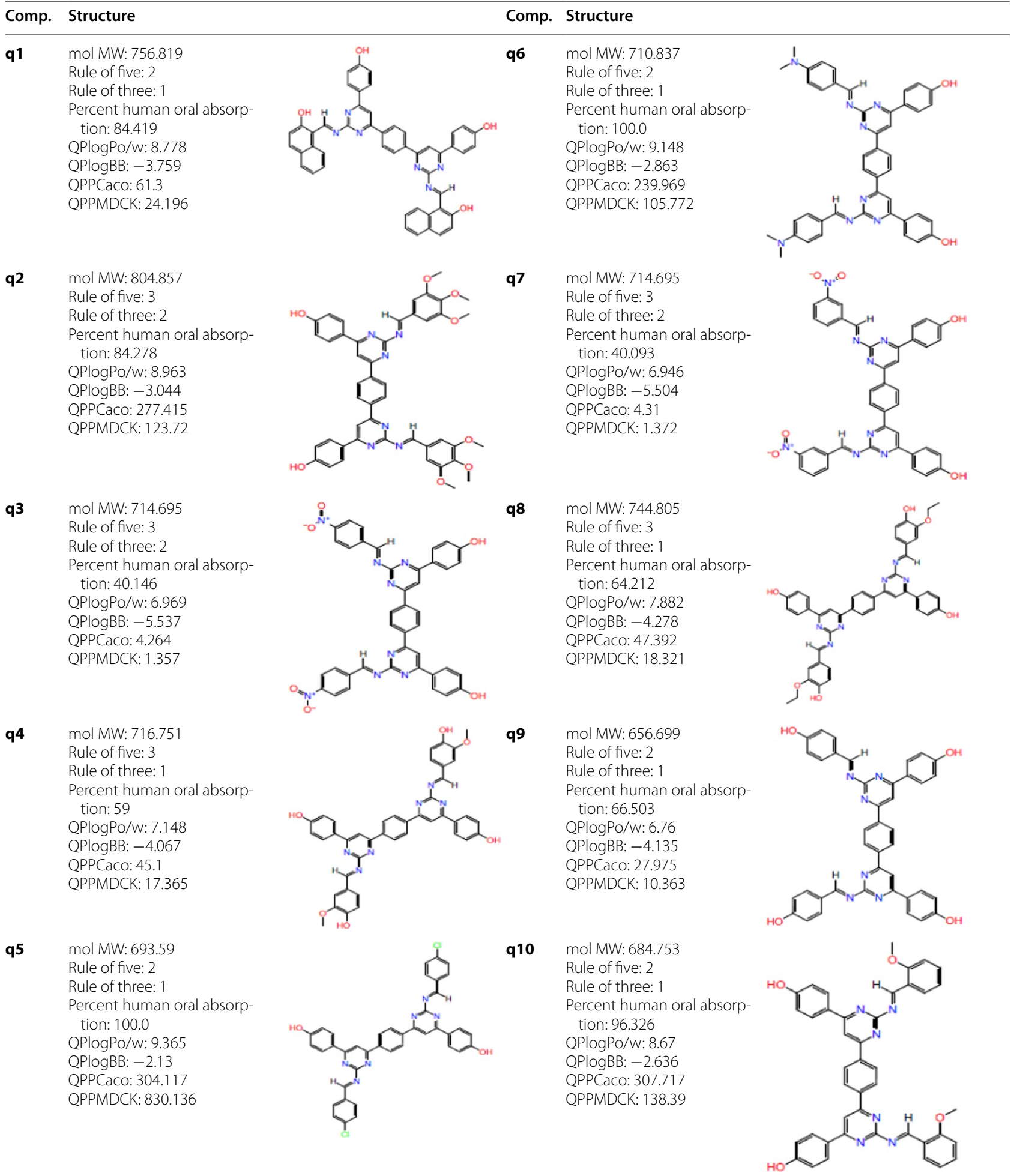


Table 2 continued

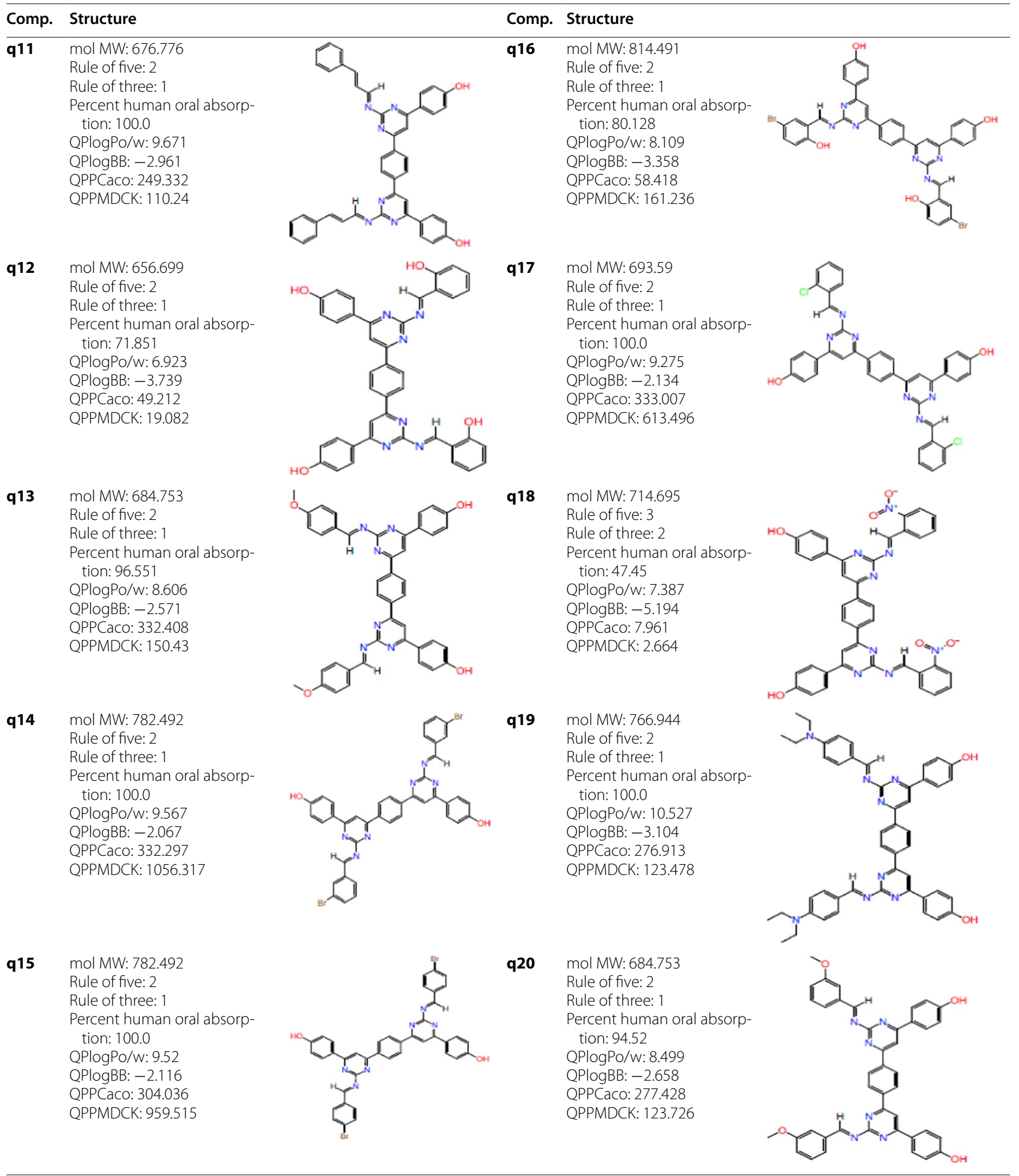


bis(2-amino pyrimidine-6,4-diyl))diphenol was separated out dried and recrystallized from methanol [24].

\section{Step c: synthesis of bis-pyrimidine Schiff bases ( $q 1$ - q20) from intermediate-II $\left(4,4^{\prime}-\left(6,6^{\prime}-(1,4-\right.\right.$ phenylene $)$ bis(2-aminopyrimidine-6,4-diyl))diphenol)}

A mixture of 4,4'-(6,6'-(1,4-phenylene)bis(2-aminopyrimidine-6,4-diyl))diphenol (0.01 mol) (synthesized in previous step- $b$ ) and $0.02 \mathrm{~mol}$ of substituted aldehyde was refluxed for 3-4 $\mathrm{h}$ in methanol with few drops of glacial acetic acid. The reaction mixture was monitored by thin layer chromatography. After completion of reaction, the reaction mixture was poured into ice cold water and the precipitated title compound was filtered, dried and recrystallized from methanol.

\section{Spectral characteristic of the synthesized bis-pyrimidine compounds (q1-q20) and intermediate (I and II)}

(2E,2'E)-3,3'-(1,4-Phenylene)bis(1-(4-hydroxyphenyl)prop2-en-1-one) (I) FT-IR (K-Br, cm $\left.{ }^{-1}\right): 3088$ (C-H str.), 1427 ( $\mathrm{C}=\mathrm{C}$ str.), 1693 ( $\mathrm{C}=\mathrm{O}$ str.), 1497 ( $\mathrm{C}=\mathrm{C}$ st., alkyl chain), 2864 (C-H sym. str., alkyl chain), 3363 (O-H str., Ar-OH); ${ }^{1} \mathrm{H}-$ NMR (DMSO- $\left.d_{6}\right): 6.91-7.63(\mathrm{~m}, 12 \mathrm{H}, \mathrm{Ar}-\mathrm{H}), 5.23$ (s, 2H, $\mathrm{Ar}-\mathrm{OH}), 7.59$ (d, 2H, CH), 8.06 (d, $2 \mathrm{H}, \mathrm{CH}) ;{ }^{13} \mathrm{C}-\mathrm{NMR}(\delta$, DMSO- $\left.d_{6}\right)$ : 192.92, 164.30, 145.1, 139.69, 134.78, 131.72, $130.21,129.91,116.21$.

4,4'-(6,6'-(1,4-Phenylene)bis(2-aminopyrimidine-6,4-diyl)) diphenol (II) FT-IR (K-Br, cm $\left.{ }^{-1}\right): 3058$ (C-H str.), 1537 ( $\mathrm{C}=\mathrm{C}$ str.), 1604 ( $\mathrm{C}=\mathrm{N}$ str. pyrimidine), 3331 (C-N str. $\mathrm{NH}_{2}$ ), 1388 (C-O st. and $\mathrm{OH}$ in pbv); ${ }^{1} \mathrm{H}-\mathrm{NMR}$ (DMSO$\left.\mathrm{d}_{6}\right)$ : 7.37-7.53 (m, 12H, Ar-H), 7.26 (s, 2H, CH of pyrimidine), 3.86 (s, 2H, C-NH $\left.{ }_{2}\right) ;{ }^{13} \mathrm{C}-\mathrm{NMR}\left(\delta\right.$, DMSO- $\left.d_{6}\right)$ : $193.00,192.67,167.12,139.34,139.71,129.71,129.94$, $129.77,129.30,128.16,126.61,116.16$.

1,1'-((1E,1'E)-((6,6'-(1,4-Phenylene)bis(4-(4-hydroxyphenyl) pyrimidinediyl))bis (azanylylidene))bis(methanylylidene)) bis(naphthalen-2-ol) (q1) Light greenish crystals; Yield: 70.45\%; mp: 90-92 ${ }^{\circ} \mathrm{C}$; $\mathrm{R}_{f}$ value: 0.55; IR (KBr, cm $\left.{ }^{-1}\right): 2927$ (C-H str.), 1594 (C=C str.), 1698 ( $\mathrm{N}=\mathrm{CH}$ str.), 1313 (C-N str.), 3359 (O-H str.); ${ }^{1} \mathrm{H}-\mathrm{NMR}\left(\delta\right.$, DMSO- $\left.d_{6}\right)$ : 6.96-7.87 (m, 24H, Ar-H), $8.11(\mathrm{~s}, 2 \mathrm{H}, \mathrm{N}=\mathrm{CH}), 7.70\left(\mathrm{~s}, 2 \mathrm{H},(\mathrm{CH})_{2}\right.$ of pyrimidine); ${ }^{13} \mathrm{C}-\mathrm{NMR}\left(\delta\right.$, DMSO- $\left.d_{6}\right): 163.9,118.7,128.7$, 124.1, 131.6, 129.2, 118.7, 122.1, 127.5, 112.4; CHN: Calc. $\mathrm{C}_{48} \mathrm{H}_{32} \mathrm{~N}_{6} \mathrm{O}_{4}$ : C, 76.18; H, 4.26; N, 11.10; Found: C, 76.13; $\mathrm{H}$, 4.24; N, 11.12; MS ES + (ToF): $m / z 758\left[\mathrm{M}^{+}+1\right]$.

4,4'-((E)-6,6'-(1,4-Phenylene)bis(2-((E)-(3,4,5-trimethoxybenzylidene)amino)pyrimidine-6,4-diyl))diphenol (q2) Dark yellow crystals; Yield: 78.32\%; mp: $250-252{ }^{\circ} \mathrm{C}$; $\mathrm{R}_{f}$ value: 0.15; IR (KBr, cm $\left.{ }^{-1}\right): 2830$ (C-H str.), 1604 (C=C str.), 1697 ( $\mathrm{N}=\mathrm{CH}$ str.), 1363 (C-N str.), 3352 (O-H str.),
2928 (C-H str., Ar-OCH $\left.{ }_{3}\right) ;{ }^{1} \mathrm{H}-\mathrm{NMR}\left(\delta, \mathrm{DMSO}-d_{6}\right): 7.48-$ 7.55 (m, 16H, Ar-H), 8.10 (s, 2H, N=CH), 7.71 (s, 2H, $(\mathrm{CH})_{2}$ of pyrimidine), $3.41\left\{\mathrm{~s}, 18 \mathrm{H},\left(\mathrm{OCH}_{3}\right)_{3}\right\} ;{ }^{13} \mathrm{C}-\mathrm{NMR}(\delta$, DMSO- $\left.d_{6}\right): 153.2,129.9,106.7,142.8,131.6,139.7,162.6$, 167.8,106.7, 150.9, 56.5, 56.2; CHN: Calc. $\mathrm{C}_{46} \mathrm{H}_{40} \mathrm{~N}_{6} \mathrm{O}_{8}$ : C, 68.65; H, 5.01; N, 10.44; Found: C, 68.63; H, 5.04; N, 10.43; MS ES + (ToF): $m / z 806\left[\mathrm{M}^{+}+1\right]$.

4,4'-((E)-6,6'-(1,4-Phenylene)bis(2-((E)-(4-nitrobenzylidene)amino)pyrimidine-6,4-diyl)) diphenol (q3) Dark yellow crystals; Yield: $65.34 \%$; mp: $275-277{ }^{\circ} \mathrm{C}$; $\mathrm{R}_{f}$ value: 0.52; IR ( $\mathrm{KBr}, \mathrm{cm}^{-1}$ ): 2931 (C-H str.), 1605 (C=C str.), 1700 (N=CH str.), 1301 (C-N str.), 3335 (O-H str.), 1347 $\left(\mathrm{C}-\mathrm{NO}_{2}\right.$ sym. str., $\left.\mathrm{NO}_{2}\right), 1534\left(\mathrm{C}-\mathrm{NO}_{2}\right.$ asym. str., $\left.\mathrm{NO}_{2}\right)$; ${ }^{1} \mathrm{H}-\mathrm{NMR}\left(\delta, \mathrm{DMSO}-d_{6}\right): 7.04-8.17(\mathrm{~m}, 20 \mathrm{H}, \mathrm{Ar}-\mathrm{H}), 8.10$ $(\mathrm{s}, 2 \mathrm{H}, \mathrm{N}=\mathrm{CH}), 7.70\left(\mathrm{~s}, 2 \mathrm{H},(\mathrm{CH})_{2}\right.$ of pyrimidine $) ;{ }^{13} \mathrm{C}-$ NMR $\left(\delta\right.$, DMSO-d $\left.{ }_{6}\right): 150.5,129.9,124.2,140.0,130.6$, 139.7, 158.5, 116.4, 104.1, 167.8, 160.2, 121.1; CHN: Calc. $\mathrm{C}_{40} \mathrm{H}_{26} \mathrm{~N}_{8} \mathrm{O}_{6}$ : C, 67.22; H, 3.67; N, 15.68; Found: C, 67.24; $\mathrm{H}, 3.60 ; \mathrm{N}, 15.70 ; \mathrm{MS}$ ES + (ToF): $m / z 716\left[\mathrm{M}^{+}+1\right]$.

4,4'-((1E,1'E)-((6,6'-(1,4-Phenylene)bis(4-(4-hydroxyphenyl) pyrimidine-6,2-diyl))bis(azanylylidene))bis(methanylylidene))bis(2-methoxyphenol) (q4) Dark yellow crystals; Yield: 72.25\%; mp: $280-282{ }^{\circ} \mathrm{C} ; \mathrm{R}_{f}$ value: 0.54; IR $\left(\mathrm{KBr}, \mathrm{cm}^{-1}\right)$ : 2933 (C-H str.), 1603 (C=C str.), 1698 ( $\mathrm{N}=\mathrm{CH}$ str.), 1365 (C-N str.), 3337 (O-H str.), 3064 (C-H str., Ar- $\mathrm{OCH}_{3}$ ); ${ }^{1} \mathrm{H}-\mathrm{NMR}\left(\delta\right.$, DMSO- $\left.d_{6}\right)$ : 6.96-7.55 $(\mathrm{m}, 18 \mathrm{H}, \mathrm{Ar}-\mathrm{H}), 8.12$ (s, $2 \mathrm{H}, \mathrm{N}=\mathrm{CH}), 7.70\left(\mathrm{~s}, 2 \mathrm{H},(\mathrm{CH})_{2}\right.$ of pyrimidine), 3.75 (s, $\left.6 \mathrm{H},\left(\mathrm{OCH}_{3}\right)_{2}\right) ;{ }^{13} \mathrm{C}-\mathrm{NMR}\left(\delta, \mathrm{DMSO}-d_{6}\right): 153.1,148.1,128.6$, 126.0, 115.3, 110.6, 55.5, 158.5, 116.4, 162.5; CHN: Calc. $\mathrm{C}_{42} \mathrm{H}_{32} \mathrm{~N}_{6} \mathrm{O}_{6}: \mathrm{C}, 70.38 ; \mathrm{H}, 4.45 ; \mathrm{N}, 11.73$; Found: $\mathrm{C}, 70.34 ; \mathrm{H}$, 4.40; N, 11.75; MS ES + (ToF): $m / z 718\left[\mathrm{M}^{+}+1\right]$.

4,4'-((E)-6,6'-(1,4-Phenylene)bis(2-((E)-(4-chlorobenzylidene)amino)pyrimidine-6,4-diyl)) diphenol (q5) Dark yellow crystals; Yield: $70.25 \%$; mp: $123-125{ }^{\circ} \mathrm{C}$; $\mathrm{R}_{f}$ value: 0.58; IR ( $\left.\mathrm{KBr}, \mathrm{cm}^{-1}\right)$ : 3060 (C-H str.), 1604 ( $\mathrm{C}=\mathrm{C}$ str.), $1700(\mathrm{~N}=\mathrm{CH}$ str.), 1384 ( $\mathrm{C}-\mathrm{N}$ str.), 3333 (O-H str.), $776\left(\mathrm{C}-\mathrm{Cl}\right.$ str. phenyl nucleus); ${ }^{1} \mathrm{H}-\mathrm{NMR}\left(\delta\right.$, DMSO- $\left.d_{6}\right)$ : 6.91-7.61 (m, 20H, Ar-H), 8.10 (s, 2H, N=CH), 7.70 (s, $2 \mathrm{H},(\mathrm{CH})_{2}$ of pyrimidine); ${ }^{13} \mathrm{C}-\mathrm{NMR}\left(\delta\right.$, DMSO- $\left.d_{6}\right): 162.6$, 134.7, 131.3, 136.7, 130.1, 129.9, 128.9, 125.6, 115.4; CHN: Calc. $\mathrm{C}_{40} \mathrm{H}_{26} \mathrm{Cl}_{2} \mathrm{~N}_{6} \mathrm{O}_{2}:$ C, 69.27; $\mathrm{H}, 3.78 ; \mathrm{N}, 12.12$; Found: $\mathrm{C}$, 69.25; H, 3.77; N, 12.09; MS ES + (ToF): $m / z 695\left[\mathrm{M}^{+}+1\right]$.

4,4'-((E)-6,6'-(1,4-Phenylene)bis(2-((E)-(4-(dimethylamino) benzylidene)amino)pyrimidine-6,4-diyl))diphenol (q6) Dark yellow crystals; Yield: 72.27\%; mp: 250-252 ${ }^{\circ} \mathrm{C}$; $\mathrm{R}_{f}$ value: 0.15; IR (KBr, cm $\left.{ }^{-1}\right): 2926$ (C-H str.), 1595 (C=C str.), 1697 ( $\mathrm{N}=\mathrm{CH}$ str.), 1353 (C-N str.), 3405 (O-H str.), $2830\left(\mathrm{~N}-\mathrm{CH}_{3}\right.$ str.); ${ }^{1} \mathrm{H}-\mathrm{NMR}\left(\delta, \mathrm{DMSO}-d_{6}\right)$ : 6.78-7.54 (m, $20 \mathrm{H}, \mathrm{Ar}-\mathrm{H}), 8.10$ (s, 2H, N=CH), $2.89\left(\mathrm{~s}, 12 \mathrm{H},\left(\mathrm{CH}_{3}\right)_{2}\right)$, 
$7.72\left(\mathrm{~s}, 2 \mathrm{H},(\mathrm{CH})_{2}\right.$ of pyrimidine); ${ }^{13} \mathrm{C}-\mathrm{NMR}\left(\delta\right.$, DMSO- $\left.d_{6}\right)$ : 131.5, 129.9, 124.4, 111.0, 39.9, 158.7, 116.5, 167.1, 144.5, 130.1, 133.1; CHN: Calc. $\mathrm{C}_{44} \mathrm{H}_{38} \mathrm{~N}_{8} \mathrm{O}_{2}$ : C,74.35; $\mathrm{H}, 5.39 ; \mathrm{N}$, 15.76; Found: C, 74.30; H, 5.35; N, 15.72; MS ES + (ToF): $m / z 712\left[\mathrm{M}^{+}+1\right]$.

4,4'-((E)-6,6'-(1,4-Phenylene)bis(2-((E)-(3-nitrobenzylidene) amino)pyrimidine-6,4-diyl)) diphenol (q7) Yellow crystals; Yield: $70.82 \%$; mp: $251-253{ }^{\circ} \mathrm{C}$; $\mathrm{R}_{f}$ value: 0.54 ; IR ( $\mathrm{KBr}$, $\mathrm{cm}^{-1}$ ): 2927 (C-H str.), 1629 (C=C str.), 1698 ( $\mathrm{N}=\mathrm{CH}$ str.), 1352 (C-N str.), 3386 (O-H str.), 1602 ( $\mathrm{NO}_{2}$ str.), 814 (C-N str., $\left.-\mathrm{NO}_{2}\right) ;{ }^{1} \mathrm{H}-\mathrm{NMR}\left(\delta\right.$, DMSO- $\left.d_{6}\right): 7.50-8.69(\mathrm{~m}, 20 \mathrm{H}$, $\mathrm{Ar}-\mathrm{H}), 8.10(\mathrm{~s}, 2 \mathrm{H}, \mathrm{N}=\mathrm{CH}), 7.70\left(\mathrm{~s}, 2 \mathrm{H},(\mathrm{CH})_{2}\right.$ of pyrimidine); ${ }^{13} \mathrm{C}$-NMR $\left(\delta\right.$, DMSO- $\left.d_{6}\right): 139.7,137.1,134.8,130.9$, 129.9, 128.5, 126.5, 124.0; CHN: Calc. $\mathrm{C}_{40} \mathrm{H}_{26} \mathrm{~N}_{8} \mathrm{O}_{6}$ : C, 67.22; H, 3.67; N, 15.68; Found: C, 67.20; H, 3.70; N, 15.63; MS ES + (ToF): $m / z 716\left[\mathrm{M}^{+}+1\right]$.

4,4'-((1E,1'E)-((6,6'-(1,4-Phenylene)bis(4-(4-hydroxyphenyl) pyrimidine-6,2-diyl))bis(azanyl ylidene))bis(methanylylidene))bis(2-ethoxyphenol) (q8) Yellow crystals; Yield: 64.33\%; mp: $260-262^{\circ} \mathrm{C}$; $\mathrm{R}_{f}$ value: 0.25 ; $\mathrm{IR}\left(\mathrm{KBr}, \mathrm{cm}^{-1}\right): 2928$ (C-H str.), 1597 ( $\mathrm{C}=\mathrm{C}$ str.), 1629 ( $\mathrm{N}=\mathrm{CH}$ str.), 1353 (C-N str.), 3408 (O-H str.), $2830\left(\mathrm{C}-\mathrm{H}\right.$ str., $\left.-\mathrm{OC}_{2} \mathrm{H}_{5}\right) ;{ }^{1} \mathrm{H}-\mathrm{NMR}(\delta$, DMSO- $\left.d_{6}\right): 6.90-7.53(\mathrm{~m}, 18 \mathrm{H}, \mathrm{Ar}-\mathrm{H}), 8.10(\mathrm{~s}, 2 \mathrm{H}, \mathrm{N}=\mathrm{CH})$, $7.72\left(\mathrm{~s}, 2 \mathrm{H},(\mathrm{CH})_{2}\right.$ of pyrimidine), $4.08\left\{\mathrm{q}, 4 \mathrm{H},\left(\mathrm{CH}_{2}\right)_{2}, 1.34\right.$ $\left(\mathrm{t}, 6 \mathrm{H},\left(\mathrm{CH}_{3}\right)_{2}\right\} ;{ }^{13} \mathrm{C}-\mathrm{NMR}\left(\delta\right.$, DMSO- $\left.d_{6}\right)$ : 147.4, 131.3, 129.9, 128.0, 126.0, 115.5, 111.7, 63.7, 14.5; CHN: Calc. $\mathrm{C}_{44} \mathrm{H}_{36} \mathrm{~N}_{6} \mathrm{O}_{6}$ : C, 70.96; H, 4.87; N, 11.28; Found: C, 70.91; H, 4.83; N, 11.23; MS ES + (ToF): $m / z 746\left[\mathrm{M}^{+}+1\right]$.

4,4'-((E)-6,6'-(1,4-Phenylene)bis(2-((E)-(4-hydroxybenzylidene)amino)pyrimidine-6,4-diyl)) diphenol (q9) Yellow crystals; Yield: $73.45 \%$; mp: $200-202{ }^{\circ} \mathrm{C}$; $\mathrm{R}_{f}$ value: 0.16 ; IR ( $\mathrm{KBr}, \mathrm{cm}^{-1}$ ): 2927 (C-H str.), 1509 (C=C str.), 1697 ( $\mathrm{N}=\mathrm{CH}$ str.), 1354 (C-N str.), 3387 (O-H str.); ${ }^{1} \mathrm{H}-\mathrm{NMR}$ $\left(\delta\right.$, DMSO- $\left.d_{6}\right): 6.91-7.53(\mathrm{~m}, 20 \mathrm{H}, \mathrm{Ar}-\mathrm{H}), 8.10(\mathrm{~s}, 2 \mathrm{H}$, $\mathrm{N}=\mathrm{CH}), 7.72\left(\mathrm{~s}, 2 \mathrm{H},(\mathrm{CH})_{2}\right.$ of pyrimidine); ${ }^{13} \mathrm{C}-\mathrm{NMR}(\delta$, DMSO- $\left.d_{6}\right): 139.7,132.0,131.3,129.9,115.0,158.1,116.4$, 162.4, 104.1, 133.1, 167.5, 160.1; CHN: Calc. $\mathrm{C}_{40} \mathrm{H}_{28} \mathrm{~N}_{6} \mathrm{O}_{4}$ : C,73.16; H, 4.30; N, 12.80; Found: C, 73.13; H, 4.34; N, 12.84; MS ES + (ToF): $m / z 658\left[\mathrm{M}^{+}+1\right]$.

4,4'-((E)-6,6'-(1,4-Phenylene)bis(2-((E)-(2-methoxybenzylidene)amino)pyrimidine-6,4-diyl)) diphenol (q10) Yellow crystals; Yield: $77.34 \%$; mp: $244-246{ }^{\circ} \mathrm{C}$; $\mathrm{R}_{f}$ value: 0.33 ; IR $\left(\mathrm{KBr}, \mathrm{cm}^{-1}\right): 2830$ (C-H str.), 1540 (C=C str.), 1604 ( $\mathrm{N}=\mathrm{CH}$ str.), 1353 (C-N str.), 3357 (O-H str.), 2931(C-H str., $\left.\mathrm{Ar}-\mathrm{OCH}_{3}\right) ;{ }^{1} \mathrm{H}-\mathrm{NMR}\left(\delta\right.$, DMSO- $\left.d_{6}\right)$ : 7.00-7.55 (m, $20 \mathrm{H}, \mathrm{Ar}-\mathrm{H}), 8.12(\mathrm{~s}, 2 \mathrm{H}, \mathrm{N}=\mathrm{CH}), 7.70\left(\mathrm{~s}, 2 \mathrm{H},(\mathrm{CH})_{2}\right.$ of pyrimidine), $3.58\left\{\mathrm{~s}, 6 \mathrm{H},\left(\mathrm{OCH}_{3}\right)_{2}\right\} ;{ }^{13} \mathrm{C}-\mathrm{NMR}(\delta$, DMSO$\left.d_{6}\right): 129.9,127.6,120.5,55.8,158.5,116.4,125.7,167.8$, 130.2, 132.1, 55.9; CHN: Calc. $\mathrm{C}_{42} \mathrm{H}_{32} \mathrm{~N}_{6} \mathrm{O}_{4}$ : C, 73.67; $\mathrm{H}$,
4.71; N, 12.27; Found: C, 73.63; H, 4.74; N, 12.22; MS $\mathrm{ES}+(\mathrm{ToF}): m / z 686\left[\mathrm{M}^{+}+1\right]$.

4, 4'-(6,6'-(1,4-Phenylene)bis(2-((E)-((E)-3-phenylallylidene)amino)pyrimidine-6,4-diyl)) diphenol (q11) Yellow crystals; Yield: $62.33 \%$; mp: $250-252{ }^{\circ} \mathrm{C}$; $\mathrm{R}_{f}$ value: 0.45 ; IR ( $\left.\mathrm{KBr}, \mathrm{cm}^{-1}\right)$ : 3059 (C-H str.), 1538 (C=C str.), 1699 ( $\mathrm{N}=\mathrm{CH}$ str.), 1386 (C-N str.), 3330 (O-H str.), 2932 (C-H str., aliphatic), $1606\left(\mathrm{C}=\mathrm{C}\right.$ str., alkyl chain); ${ }^{1} \mathrm{H}-\mathrm{NMR}$ $\left(\delta\right.$, DMSO- $\left.d_{6}\right): 6.85-7.53(\mathrm{~m}, 22 \mathrm{H}, \mathrm{Ar}-\mathrm{H}), 7.75(\mathrm{~s}, 2 \mathrm{H}$, $\mathrm{N}=\mathrm{CH}), 7.7\left(\mathrm{~s}, 2 \mathrm{H},(\mathrm{CH})_{2}\right.$ of pyrimidine $) ;{ }^{13} \mathrm{C}-\mathrm{NMR}(\delta$, DMSO- $\left.d_{6}\right)$ : $131.1,129.9,128.6,128.4,158.5,116.4,125.7$, 162.5, 163.6, 138.2, 126.4, 135.4; CHN: Calc. $\mathrm{C}_{44} \mathrm{H}_{32} \mathrm{~N}_{6} \mathrm{O}_{2}$ : C, 78.09; H, 4.77; N, 12.42; Found: C, 78.05; H, 4.72; N, 12.39; MS ES + (ToF): $m / z 678\left[\mathrm{M}^{+}+1\right]$.

4,4'-((E)-6,6'-(1,4-Phenylene)bis(2-((E)-(2-hydroxybenzylidene)amino)pyrimidine-6,4-diyl)) diphenol(q12) Yellow crystals; Yield: $81.84 \%$; mp: $195-197^{\circ} \mathrm{C}$; $\mathrm{R}_{f}$ value: 0.80 ; IR ( $\left.\mathrm{KBr}, \mathrm{cm}^{-1}\right): 2930$ (C-H str.), 1540 (C=C str.), 1699 ( $\mathrm{N}=\mathrm{CH}$ str.), 1354 (C-N str.), 3372 (O-H str.); ${ }^{1} \mathrm{H}-\mathrm{NMR}$ $\left(\delta\right.$, DMSO- $\left.d_{6}\right): 6.96-7.54(\mathrm{~m}, 20 \mathrm{H}, \mathrm{Ar}-\mathrm{H}), 8.10(\mathrm{~s}, 2 \mathrm{H}$, $\mathrm{N}=\mathrm{CH}), 7.72\left(\mathrm{~s}, 2 \mathrm{H},(\mathrm{CH})_{2}\right.$ of pyrimidine $) ;{ }^{13} \mathrm{C}-\mathrm{NMR}(\delta$, DMSO- $\left.d_{6}\right): 129.9,158.5,116.4,128.9,125.7,162.5,167.8$, 118.5, 130.6, 121.5, 132.1, 161.4; CHN: Calc. $\mathrm{C}_{40} \mathrm{H}_{28} \mathrm{~N}_{6} \mathrm{O}_{4}$ : C, 73.16; H, 4.30; N, 12.80; Found: C, 73.13; H, 4.34; N, 12.78; MS ES + (ToF): $m / z 658\left[\mathrm{M}^{+}+1\right]$.

4,4'-((E)-6,6'-(1,4-Phenylene)bis(2-((E)-(4-methoxybenzylidene)amino)pyrimidine-6,4-diyl)) diphenol(q13) Yellow crystals; Yield: $89.14 \%$; mp: $255-257{ }^{\circ} \mathrm{C}$; $\mathrm{R}_{f}$ value: 0.32 ; IR ( $\mathrm{KBr}, \mathrm{cm}^{-1}$ ): 2830 (C-H str.), 1540 (C=C str.), 1699 ( $\mathrm{N}=\mathrm{CH}$ str.), 1354 (C-N str.), 3359 (O-H str.), 2931 (C-H str., $\left.\mathrm{Ar}-\mathrm{OCH}_{3}\right) ;{ }^{1} \mathrm{H}-\mathrm{NMR}\left(\delta, \mathrm{DMSO}-d_{6}\right)$ : $7.12-7.59(\mathrm{~m}$, $20 \mathrm{H}, \mathrm{Ar}-\mathrm{H}), 8.10(\mathrm{~s}, 2 \mathrm{H}, \mathrm{N}=\mathrm{CH}), 7.68\left(\mathrm{~s}, 2 \mathrm{H},(\mathrm{CH})_{2}\right.$ of pyrimidine), $3.74\left(\mathrm{~s}, 6 \mathrm{H}, \mathrm{OCH}_{3}\right) ;{ }^{13} \mathrm{C}-\mathrm{NMR}(\delta$, DMSO$\left.d_{6}\right)$ : 131.7, 129.9, 114.4, 125.8, 162.6, 104.3, 167.8, 160.1, 128.0, 133.1, 158.1, 116.4, 126.1, 163.0, 55.6; CHN: Calc. $\mathrm{C}_{42} \mathrm{H}_{32} \mathrm{~N}_{6} \mathrm{O}_{4}: \mathrm{C}, 73.67 ; \mathrm{H}, 4.71 ; \mathrm{N}, 12.27$; Found: $\mathrm{C}$, 73.62; $\mathrm{H}, 4.75 ; \mathrm{N}, 12.31$; MS ES + (ToF): $m / z 686\left[\mathrm{M}^{+}+1\right]$.

4,4'-((E)-6,6'-(1,4-Phenylene)bis(2-((E)-(3-bromobenzylidene)amino)pyrimidine-6,4-diyl)) diphenol (q14) Yellow crystals; Yield: 66.90\%; mp: $205-207{ }^{\circ} \mathrm{C}$; $\mathrm{R}_{f}$ value: 0.27; IR ( $\left.\mathrm{KBr}, \mathrm{cm}^{-1}\right)$ : 3057 (C-H str.), 1538 ( $\mathrm{C}=\mathrm{C}$ str.), 1699 ( $\mathrm{N}=\mathrm{CH}$ str.), 1387 (C-N str.), 3329 (O-H str.), 549 (C-Br str); ${ }^{1} \mathrm{H}-\mathrm{NMR}\left(\delta\right.$, DMSO- $\left.d_{6}\right): 7.36-782(\mathrm{~m}, 20 \mathrm{H}$, $\mathrm{Ar}-\mathrm{H}), 8.12(\mathrm{~s}, 2 \mathrm{H}, \mathrm{N}=\mathrm{CH}), 7.72\left(\mathrm{~s}, 2 \mathrm{H},(\mathrm{CH})_{2}\right.$ of pyrimidine); ${ }^{13} \mathrm{C}$-NMR $\left(\delta\right.$, DMSO- $\left.d_{6}\right): 139.7,137.0,131.9,128.1$, 122.3, 158.5, 116.3, 167.6, 134.0, 162.3, 104.1; CHN: Calc. $\mathrm{C}_{40} \mathrm{H}_{26} \mathrm{Br}_{2} \mathrm{~N}_{6} \mathrm{O}_{2}$ : C, 61.40; H, 3.35; N, 10.74; Found: C, 61.45; H, 3.30; N, 10.77; MS ES + (ToF): $m / z 783\left[\mathrm{M}^{+}+1\right]$. 
4,4'-((E)-6,6'-(1,4-Phenylene)bis(2-((E)-(4-bromobenzylidene)amino)pyrimidine-6,4-diyl)) diphenol (q15) Yellow crystals; Yield: $72.00 \%$; mp: $217-219{ }^{\circ} \mathrm{C}$; $\mathrm{R}_{f}$ value: 0.58; IR ( $\left.\mathrm{KBr}, \mathrm{cm}^{-1}\right)$ : 3059 (C-H str.), 1538 ( $\mathrm{C}=\mathrm{C}$ str.), 1699 ( $\mathrm{N}=\mathrm{CH}$ str.), 1386 (C-N str.), 3338 (O-H str.), 1168 $\left(\mathrm{C}-\mathrm{O}-\mathrm{C}\right.$ str., $\left.\mathrm{Ar}-\mathrm{OCH}_{3}\right), 2830\left(\mathrm{C}-\mathrm{H}\right.$ str., $\left.-\mathrm{OCH}_{3}\right), 551$ (C-Br str.); ${ }^{1} \mathrm{H}-\mathrm{NMR}\left(\delta\right.$, DMSO- $\left.d_{6}\right): 7.46-7.53(\mathrm{~m}, 20 \mathrm{H}$, $\mathrm{Ar}-\mathrm{H}), 8.12(\mathrm{~s}, 2 \mathrm{H}, \mathrm{N}=\mathrm{CH}), 7.70\left(\mathrm{~s}, 2 \mathrm{H},(\mathrm{CH})_{2}\right.$ of pyrimidine); ${ }^{13} \mathrm{C}-\mathrm{NMR}\left(\delta\right.$, DMSO- $\left.d_{6}\right): 139.7,132.2,131.1,128.6$, 126.5, 158.5, 116.4, 131.8, 125.3, 167.8, 160.2; CHN: Calc. $\mathrm{C}_{40} \mathrm{H}_{26} \mathrm{Br}_{2} \mathrm{~N}_{6} \mathrm{O}_{2}:$ C, 61.40; H, 3.35; N, 10.74; Found: C, 61.45; H, 3.30; N, 10.77; MS ES + (ToF): $m / z 783\left[\mathrm{M}^{+}+1\right]$.

2,2'-((1E,1'E)-((6,6'-(1,4-Phenylene)bis(4-(4-hydroxyphenyl)pyrimidine-6,2-diyl))bis(azanyl bis(methanylylidene))bis(4-bromophenol) (q16) Yellow crystals; Yield: $83.67 \%$; $\mathrm{mp}: 296-298{ }^{\circ} \mathrm{C}$; $\mathrm{R}_{f}$ value: 0.25 ; IR $\left(\mathrm{KBr}, \mathrm{cm}^{-1}\right): 542$ (C-Br str., $\mathrm{C}_{6} \mathrm{H}_{5} \mathrm{Br}$ ), 2928 (C-H str.), 1604 ( $\mathrm{C}=\mathrm{C}$ str.), 1699 ( $\mathrm{N}=\mathrm{CH}$ str.), 1363 (C-N str.), 3357 (O-H str.); ${ }^{1} \mathrm{H}-\mathrm{NMR}\left(\delta\right.$, DMSO- $\left.d_{6}\right): 7.39-7.61(\mathrm{~m}, 18 \mathrm{H}, \mathrm{Ar}-\mathrm{H})$, $8.11(\mathrm{~s}, 2 \mathrm{H}, \mathrm{N}=\mathrm{CH}), 7.71\left(\mathrm{~s}, 2 \mathrm{H},(\mathrm{CH})_{2}\right.$ of pyrimidine); ${ }^{13} \mathrm{C}-$ $\operatorname{NMR}\left(\delta\right.$, DMSO- $\left.d_{6}\right): 158.4,163.6,104.1,167.8,160.1,128.0$, 130.0, 120.4, 133.1, 115.8, 116.4, 128.9, 125.7, 135.4, 118.2, 160.1; CHN: Calc. $\mathrm{C}_{40} \mathrm{H}_{26} \mathrm{Br}_{2} \mathrm{~N}_{6} \mathrm{O}_{4}$ : C, 58.99; H, 3.22; N, 10.32; Found: C, 58.95; H, 3.20; N, 10.35; MS ES + (ToF): $m / z 815\left[\mathrm{M}^{+}+1\right]$.

4,4'-((E)-6,6'-(1,4-Phenylene)bis(2-((E)-(2-chlorobenzylidene)amino)pyrimidine-6,4-diyl)) diphenol) (q17) Yellow crystals; Yield: $79.12 \%$; mp: $265-267{ }^{\circ} \mathrm{C}$; $\mathrm{R}_{f}$ value: 0.18 ; IR (KBr, cm $\left.{ }^{-1}\right)$ : 2925 (C-H str.), 1539 (C=C str.), 1699 ( $\mathrm{N}=\mathrm{CH}$ str.), 1363 (C-N str.), 3355 (O-H str.), 775(C-Cl str.); ${ }^{1} \mathrm{H}-\mathrm{NMR}\left(\delta\right.$, DMSO- $\left.d_{6}\right): 7.48-7.61(\mathrm{~m}, 20 \mathrm{H}, \mathrm{Ar}-\mathrm{H})$, $8.12(\mathrm{~s}, 2 \mathrm{H}, \mathrm{N}=\mathrm{CH}), 7.70\left(\mathrm{~s}, 2 \mathrm{H},(\mathrm{CH})_{2}\right.$ of pyrimidine $) ;{ }^{13} \mathrm{C}-$ $\operatorname{NMR}\left(\delta\right.$, DMSO- $\left.d_{6}\right)$ : 139.7, 135.7, 130.7, 129.7, 127.8; CHN: Calc. $\mathrm{C}_{40} \mathrm{H}_{26} \mathrm{Cl}_{2} \mathrm{~N}_{6} \mathrm{O}_{2}$ : C, 69.27; $\mathrm{H}, 3.78 ; \mathrm{N}, 12.12$; Found: $\mathrm{C}$, 69.23; H, 3.74; N, 12.10; MS ES + (ToF): $m / z 695\left[\mathrm{M}^{+}+1\right]$.

4, 4'-((E)-6, 6'-(1,4-Phenylene) bis(2-((E)-(2-nitrobenzylidene)amino)pyrimidine-6,4-diyl)) diphenol(q18) Yellow crystals; Yield: $69.23 \%$; mp: $198-200{ }^{\circ} \mathrm{C}$; $\mathrm{R}_{f}$ value: 0.16; IR ( $\left.\mathrm{KBr}, \mathrm{cm}^{-1}\right)$ : 2926 (C-H str.), 1539 (C=C str.), 1699 ( $\mathrm{N}=\mathrm{CH}$ str.), 1354 (C-N str.), 3375 (O-H str.), 1604 $\left(\mathrm{NO}_{2}\right.$ str.), 814 (C-N str., $\left.-\mathrm{NO}_{2}\right) ;{ }^{1} \mathrm{H}-\mathrm{NMR}(\delta$, DMSO$\left.d_{6}\right)$ : 7.43-8.16 (m, 20H, Ar-H), $8.12(\mathrm{~s}, 2 \mathrm{H}, \mathrm{N}=\mathrm{CH}), 7.75$ $\left(\mathrm{s}, 2 \mathrm{H},(\mathrm{CH})_{2}\right.$ of pyrimidine); ${ }^{13} \mathrm{C}-\mathrm{NMR}\left(\delta\right.$, DMSO- $\left.d_{6}\right)$ : 167.4, 139.7, 134.1, 130.5, 128.1, 126.5, 124.2; CHN: Calc. $\mathrm{C}_{40} \mathrm{H}_{26} \mathrm{~N}_{8} \mathrm{O}_{6}$ : C, 67.22; H, 3.67; N, 15.68; Found: C, 67.18; $\mathrm{H}, 3.62 ; \mathrm{N}, 15.63$; MS ES + (ToF): $m / z 716\left[\mathrm{M}^{+}+1\right]$.

4,4'-((E)-6,6'-(1,4-Phenylene)bis(2-((E)-(4-(diethylamino) benzylidene)amino)pyrimidine-6,4-diyl))diphenol (q19) Light yellow crystals; Yield: 65.33\%; mp: 249- $251^{\circ} \mathrm{C}$; $\mathrm{R}_{f}$ value: 0.23 ; IR ( $\left.\mathrm{KBr}, \mathrm{cm}^{-1}\right): 2970$ (C-H str.), 1590 ( $\mathrm{C}=\mathrm{C}$ str.), 1699 ( $\mathrm{N}=\mathrm{CH}$ str.), 1356 (C-N str.), 2830 ( $\mathrm{C}-\mathrm{H}$ str., alkyl chain), $3350\left(\mathrm{O}-\mathrm{H}\right.$ str.); ${ }^{1} \mathrm{H}-\mathrm{NMR}(\delta$, DMSO$\left.d_{6}\right)$ : 6.75-7.55 (m, 20H, Ar-H), $8.1(\mathrm{~s}, 2 \mathrm{H}, \mathrm{N}=\mathrm{CH}), 7.77$ (s, $2 \mathrm{H},(\mathrm{CH})_{2}$ of pyrimidine), $3.41\left\{\mathrm{q}, 4 \mathrm{H},\left(\mathrm{CH}_{2}\right)_{2}, 1.13\right.$ $\left(\mathrm{t}, 6 \mathrm{H},\left(\mathrm{CH}_{3}\right)_{2}\right\} ;{ }^{13} \mathrm{C}-\mathrm{NMR}\left(\delta\right.$, DMSO- $\left.d_{6}\right): 151.9,139.7$, $129.9,123.9,110.5,116.4,126.9,160.1,128.0,133.1,130.1$, 125.7, 162.6, 104.1, 167.8, 114.4, 44.5, 12.27; CHN: Calc. $\mathrm{C}_{48} \mathrm{H}_{46} \mathrm{~N}_{8} \mathrm{O}_{2}$ : C, 75.17; H, 6.05; N, 14.61; Found; C,75.14; $\mathrm{H}, 6.09 ; \mathrm{N}, 14.64 ; \mathrm{MS}$ ES + (ToF): $m / z 768\left[\mathrm{M}^{+}+1\right]$.

4,4'-((E)-6,6'-(1,4-Phenylene)bis(2-)(E)-(2-methoxybenzylidene)amino)pyrimidine-6,4-diyl)) diphenol(q20) Light yellow crystals; Yield: $89.45 \%$; mp: $274-276{ }^{\circ} \mathrm{C}$; $\mathrm{R}_{f}$ value: 0.16; IR ( $\mathrm{KBr}, \mathrm{cm}^{-1}$ ): 2931 (C-H str.), 1605 (C=C str.), 1699 ( $\mathrm{N}=\mathrm{CH}$ str.), 1365 (C-N str.), 3350 (O-H str.), 3058 (C-H str., $\left.-\mathrm{OCH}_{3}\right) ;{ }^{1} \mathrm{H}-\mathrm{NMR}\left(\delta\right.$, DMSO- $\left.d_{6}\right): 6.91-7.54(\mathrm{~m}, 20 \mathrm{H}$, $\mathrm{Ar}-\mathrm{H}), 8.1(\mathrm{~s}, 2 \mathrm{H}, \mathrm{N}=\mathrm{CH}), 7.62\left(\mathrm{~s}, 2 \mathrm{H},(\mathrm{CH})_{2}\right.$ of pyrimidine), 3.75 (s, $\left.2 \mathrm{H}, \mathrm{OCH}_{3}\right) ;{ }^{13} \mathrm{C}-\mathrm{NMR}\left(\delta\right.$, DMSO- $\left.d_{6}\right)$ : 159.1 , 130.3, 129.9, 129.1, 128.1, 122.4, 120.9, 118.7, 113.8, 116.3, 126.9, 125.7, 163.6, 104.1, 134.8, 121.5, 128.8, 160.8, 55.3; CHN: Calc. $\mathrm{C}_{42} \mathrm{H}_{32} \mathrm{~N}_{6} \mathrm{O}_{4}$ : C, 73.67; H, 4.71; N, 12.27; Found: C, 73.62; H, 4.75; N, 12.22; MS ES + (ToF): $m / z 686\left[\mathrm{M}^{+}\right.$ $+1]$.

\section{In vitro antimicrobial assay}

The in vitro antimicrobial study of the synthesized bispyrimidines was evaluated against Gram +ve bacterial species: S. aureus (MTCC 3160), B. subtilis (MTCC 441), Gram -ve species: E. coli (MTCC 443) and fungus species: A. niger (MTCC 281) and C. albicans (MTCC 227) by tube dilution technique [25]. Dilutions of test and reference drug in double strength nutrient broth media I.P. was used for antibacterial study and Sabouraud dextrose broth media I.P. was used for the antifungal study. The stock solution was prepared for the test compounds (q1q20) and reference drugs (norfloxacin and fluconazole) in dimethyl sulfoxide (DMSO) to get a concentration of $100 \mu \mathrm{g} / \mathrm{mL}$ and this stock solution was used for further tube dilution with six concentration of 50, 25, 12.5, 6.25, 3.125 and $1.562 \mu \mathrm{g} / \mathrm{mL}$ for the antimicrobial study [26]. The MIC values of synthesized bis-pyrimidine Schiff base derivatives were recorded at different incubation period: $37 \pm 1{ }^{\circ} \mathrm{C}$ (bacterial species) for $24 \mathrm{~h}, 37 \pm 1{ }^{\circ} \mathrm{C}$ (C. albicans) for $48 \mathrm{~h}$ and $25 \pm 1{ }^{\circ} \mathrm{C}$ (A. niger) for 7 days and the antimicrobial results have been recorded in terms of minimum inhibitory concentration values in $\mu \mathrm{mol} / \mathrm{mL}$.

\section{In vitro cytotoxicity assay}

The anticancer screening of synthesized compounds was determined against human colorectal carcinoma [HCT-116 (ATCC (American Type Culture Collection) CCL-247)] cancer cell line using sulforhodamine B 
(SRB) assay. The optimal cell count ( 2500 cells $/ 180 \mu \mathrm{L} /$ well) of HCT-116 was seeded onto the 96 flat-bottom well plates and incubated overnight to allow attachment. $20 \mu \mathrm{L}$ of pure compounds at tenfold the final concentrations were added in quadruplicates. Both drug-free control and treated cells were then incubated for $72 \mathrm{~h}$. The drug-induced cytotoxicity was assessed using the SRB assay as previously described by Skehan et al. [27], but with minor modifications. Briefly, upon removal of media, cells in each well were fixed with $200 \mu \mathrm{L}$ of $10 \%$ cold TCA [Sigma-Aldrich, St Louis, Missouri, USA] (w/v; in deionised water). After incubation at $40{ }^{\circ} \mathrm{C}$ for $30 \mathrm{~min}$, the individual wells were rinsed with water for five times. Cells in each well were allowed to stain in $100 \mu \mathrm{L}$ of $0.4 \%$ SRB [Sigma-Aldrich, St Louis, Missouri, USA] (w/v; in 1\% acetic acid) for $15 \mathrm{~min}$. Unincorporated dye was rinsed off with $1 \%$ acetic acid [Fisher Scientific, Loughborough, Leicestershire, UK] (v/v; in deionised water) and plates were left to air-dry at room temperature overnight. The air-dried plates were placed on a plate shaker and bound SRB was solubilised in $100 \mu \mathrm{L}$ of $10 \mathrm{mM}$ Tris base solution [Sigma-Aldrich, St Louis, Missouri, USA]. Absorbance was measured by a computer-interfaced 96-well plate spectrophotometer at $570 \mathrm{~nm}$. A dose-response curve (percentage of cell viability vs log concentration) was plotted from which the IC50 value of each molecule against each cell type was graphically determined.

\section{Molecular docking protocol}

In order to reveal the binding modes of synthesized twenty bis-pyrimidine Schiff base derivatives, docking simulation was performed targeting the crystal structure of cyclin-dependent kinase 8 (CDK8). Prior to docking, the crystal structure [PDB ID: 5FGK] was retrieved from the protein data bank (PDB) [28]. The CDK8 structure was prepared using protein preparation wizard and optimized by removing the water molecules, hetero atoms and co-factors. Hydrogen, missing atoms, bonds and charges were computed through Maestro [Schrodinger Release 2015-1: Maestro, version 10.1, Schrodinger, LLC, New York, 2015]. The synthesized twenty.

Bis-pyrimidine Schiff base derivatives were used for docking. Meanwhile, the bis-pyrimidine Schiff base derivatives were prepared and optimized using built and LigPrep module implemented in Schrodinger Maestro. Ligands preparation includes generating various tautomers, assigning bond orders, ring conformations and stereo chemistries. All the conformations generated were minimized using OPLS2005 force field prior to docking study.

Molecular docking studies were performed using GOLD (Genetic Optimization for Ligand Docking) program version 5.1. GOLD is an automated docking program that employs the genetic algorithm to search the ligand conformational flexibility with a partial flexibility of protein's active site [29]. GOLD uses genetic algorithm method for protein-ligand docking and it is well-known for its performance and accuracy specifically for the protein targets with buried active site. The GOLD software has four scoring functions namely ChemPLP, GoldScore, ChemScore, and ASP (the Astex Statistical Potential) which take into account the terms of hydrogen bonding, van der Waal and intramolecular energies. In the present GOLD docking study targeting cyclin-dependent kinase CDK8, the ChemPLP scoring function was used as it outperformed the other scoring function. All the bispyrimidine derivatives were docked to cyclin-dependent kinase CDK8 active site, using co-complex 5XG ligand as the reference with $12 \mathrm{~A}$ radius. Further, the population size was set to (100); selection-pressure (1.1); number of operations $(10,000)$; number of islands (1); niche size (2); operator weights for migrate (0), mutate (100), and crossover (100) and with 100 GA run. Results divergent by less than $1.50 \mathrm{~A}$ in ligand-all atom RMSDs were clustered together. Best cluster poses and top ranked scores were saved and visually analyzed by Pymol [PyMOL Molecular Graphics System, Schrödinger L, NY, USA, 2010.]. Additional, Qikprop prediction of ADME properties were done for all the synthesized twenty bis-pyrimidine derivatives [Rapid ADME, QikProp, Schrödinger LLC, New York, 2012].

\section{Conclusion}

Summarizingly, bis-pyrimidine Schiff bases were synthesized and characterized by physicochemical and spectral means and the spectral data was found in agreement with the assigned molecular structures. The in vitro antimicrobial screening of synthesized compounds indicated that compounds q1, q16, q19 and q20 exhibited appreciable antimicrobial potential. The anticancer screening results demonstrated that compound $\mathbf{q 1}\left(\mathrm{IC}_{50}=0.18 \mu \mathrm{mol} /\right.$ $\mathrm{mL}$ ) is the most active one against colorectal (HCT 116) cancer cell line. Molecular docking studies indicated the compound $\mathbf{q} \mathbf{1}$ being the most active molecule has the maximum hydrogen bond interaction (four) and $\pi-\pi$ stacking (three) network among the bis-pyrimidine Schiff bases. The synthesized compounds may exhibit their anticancer and antimicrobial activity by the inhibition of enzymes CDK- 8 and DHFR respectively. The current study has widened the scope of developing the most active bis-pyrimidine molecules as promising antimicrobial and anticancer agents.

\section{Authors' contributions}

Authors BN and SK have designed, synthesized and carried out the antimicrobial activity and SML, KR, MV, SAAS and MS have carried out the spectral analysis, interpretation and anticancer evaluation of synthesized compounds. All authors read and approved the final manuscript. 


\begin{abstract}
Author details
1 Faculty of Pharmaceutical Sciences, Maharshi Dayanand University, Rohtak 124001, India. ${ }^{2}$ Faculty of Pharmacy, Universiti Teknologi MARA (UiTM), Puncak Alam Campus, 42300 Bandar Puncak Alam, Selangor Darul Ehsan, Malaysia. ${ }^{3}$ Collaborative Drug Discovery Research (CDDR) Group, Pharmaceutical Life Sciences Community of Research, Universiti Teknologi MARA (UiTM), 40450 Shah Alam, Selangor Darul Ehsan, Malaysia. ${ }^{4}$ Department of Pharmacology and Toxicology, College of Pharmacy, Qassim University, Buraidah 51452, Kingdom of Saudi Arabia. ${ }^{5}$ Atta-ur-Rahman Institute for Natural Products Discovery (AuRIns), Universiti Teknologi MARA, Puncak Alam Campus, 42300 Bandar Puncak Alam, Selangor Darul Ehsan, Malaysia. ${ }^{6}$ Integrative Pharmacogenomics Institute (iPROMISE), Universiti Teknologi MARA (UiTM), Puncak Alam Campus, 42300 Bandar Puncak Alam, Selangor Darul Ehsan, Malaysia.
\end{abstract}

\section{Acknowledgements}

The authors are thankful to Head, Department of Pharmaceutical Sciences, M. D. University, Rohtak, for providing necessary facilities to carry out this research work.

\section{Competing interests}

The authors declare that they have no competing interests.

Ethics approval and consent to participate

Not applicable.

\section{Funding}

Not applicable.

\section{Publisher's Note}

Springer Nature remains neutral with regard to jurisdictional claims in published maps and institutional affiliations.

Received: 13 August 2017 Accepted: 6 September 2017 Published online: 18 September 2017

\section{References}

1. Jain S, Paliwal PK, Babu GN, Bhatewara A (2014) DABCO promoted onepot synthesis of dihydropyrano(c)chromene and pyrano[2,3-d]pyrimidine derivatives and their biological activities. J Saudi Chem S 18:535-540

2. Zhu W, Sun C, Xu S, Wu C, Wu J, Xu M, Zhao H, Chen L, Zeng W, Zheng P (2014) Design, synthesis, anticancer activity and docking studies of novel 4-morpholino-7,8-dihydro-5H-thiopyrano[4,3-d]pyrimidine derivatives as mTOR inhibitors. Bioorg Med Chem 22:6746-6754

3. Ivanov MA, Aleksandrova LA (2013) Bicyclic furano-, pyrrolo- and thiopheno[2,3- $d$ ] derivatives of pyrimidine nucleosides: synthesis and antiviral properties. Russ J Bioorg Chem 39(1):22-39

4. Alam MM, Akhter Husain MA, Marella A, Tanwar OP, Ali R, Hasan SM, Kumar H, Haider R, Shaquiquzzaman M (2012) Anti-inflammatory and antimicrobial activity of 4,5-dihydropyrimidine-5-carbonitrile derivatives and their synthesis and spectral elucidation. Acta Pol Pharm 69(6):1077-1085

5. Bari SB, Haswani NG (2017) Design, synthesis and molecular docking study of thienopyrimidin-4(3H)-thiones as antifungal agents. J Saudi Chem Soc 21:S264-S274

6. Ashour MH, Shaaban OG, Rizk OH, El-Ashmawy IM (2013) Synthesis and biological evaluation of thieno[2', $\left.3^{\prime}: 4,5\right]$ pyrimido[1,2-b][1, 2, 4]triazines and thieno[2,3-d][1,2,4] triazolo[1,5-a]pyrimidines as anti-inflammatory and analgesic agents. Eur J Med Chem 62:341-351

7. Shaquiquzzaman M, Khan SA, Amir M, Alam MM (2012) Synthesis, anticonvulsant and neurotoxicity evaluation of some new pyrimidine5-carbonitrile derivatives. Saudi Pharm J 20:149-154

8. Attri P, Bhatia R, Gaur J, Arora B, Gupta A, Kumar N, Choi EH (2017) Triethylammonium acetate ionic liquid assisted one-pot synthesis of dihydropyrimidinones and evaluation of their antioxidant and antibacterial activities. Arab J Chem 10:206-214

9. Chaudhary A, Sharma PK, Verma P, Dudhe R (2011) Synthesis of novel pyrimidine derivative and its biological evaluation. Analele UniversităŃii din Bucuresti - Chimie (serie nouă) 20(2):123-140
10. Suryawanshi SN, Kumar S, Shivahare R, Pandey S, Gupta S, Tiwari A (2013) Design, synthesis and biological evaluation of aryl pyrimidine derivatives as potential leishmanicidal agents. Bioorg Med Chem Lett 23:5235-5238

11. Kenchappa R, Bodke YD, Chandrashekar A, Telkar S, Manjunatha SK, Sindhe MA (2017) Synthesis of some 2,6-bis(1-coumarin-2-yl)-4-(4substituted phenyl)pyridine derivatives as potent biological agents. Arab J Chem 10:S1336-S1344

12. Chandrasekaran S, Nagarajan S (2005) Microwave-assisted synthesis and anti-bacterial activity of some 2-amino-6-aryl-4-(2-thienyl)pyrimidines. II Farmaco 60:279-282

13. Fathalla OA, Zeid IF, Haiba ME, Soliman AM, Abd-Elmoez SI, El-Serwy WS (2009) Synthesis, antibacterial and anticancer evaluation of some pyrimidine derivatives. World J Chem 4:127-132

14. Nagaraj A, Reddy CS (2008) Synthesis and biological study of novel bischalcones, bis-thiazines and bis-pyrimidines. J Iran Chem Soc 5:262-267

15. Kandeel MM, Mounir AA, Refaat HM, Kassab AE (2012) Synthesis of effective anticancer thieno[2,3-d]pyrimidine-4-ones and thieno[3,2-e] triazolo[4,3-c]pyrimidines. Int J Pharm Pharm Sci 4(3):438-448

16. Abdellatif KRA, Abdelall EKA, Abdelgawad MA, Ahmed RR, Bakr RB (2014) Synthesis and anticancer activity of some new pyrazolo[3,4-d]pyrimidin4-one derivatives. Molecules 19:3297-3309

17. Kumar P, Narasimhan B, Yogeeswari P, Sriram D (2010) Synthesis and antitubercular activities of substituted benzoic acid $N^{\prime}$-(substituted benzylidene/furan-2-ylmethylene)-N-(pyridine-3-carbonyl)-hydrazides. Eur J Med Chem 45(2010):6085-6089

18. Maddila S, Gorle S, Seshadri N, Lavanya P, Jonnalagadda SB (2016) Synthesis, antibacterial and antifungal activity of novel benzothiazole pyrimidine derivatives. Arab J Chem 9:681-687

19. Sharma V, Chitranshi N, Agarwal AK (2014) Significance and biological importance of pyrimidine in the microbial world. Int J Med Chem 2014:1-31

20. Kaur M, Velmurugan B, Tyagi A, Agarwal C, Singh RP, Agarwal R (2010) Silibinin suppresses growth of human colorectal carcinoma SW480 Cells in culture and xenograft through downregulation of $\beta$-catenin-dependent signaling. Neoplasia 12(5):415-424

21. Mariaule G, Belmont P (2014) Cyclin-Dependent kinase inhibitors as marketed anticancer drugs: where are we now? A short survey. Molecules 19:14366-14382

22. Lipinski CA, Lombardo F, Dominy BW, Feeney PJ (2001) Experimental and computational approaches to estimate solubility and permeability in drug discovery and development settings. Adv Drug Deliv Rev 46:1-26

23. Asiri AM, Khan SA (2011) Synthesis and anti-bacterial activities of a bis-chalcone, derived from thiophene and its bis-cyclized products. Molecules 16:523-531

24. Parveen H, Hayat F, Mukhtar S, Salahuddin A, Khan A, Islam F, Azam A (2011) Synthesis, characterization and biological evaluation of novel 2,4,6-trisubstituted bis-pyrimidine derivatives. Eur J Med Chem 46:4669-4675

25. Cappuccino JC, Sherman N (1999) Microbiology-a laboratory manual. Addison Wesley, California, p 263

26. The Indian Pharmacopoeia Commission (2007) Pharmacopoeia of India, vol. I. Controller of publication, ministry of health department, Govt. of India, New Delhi, p 37

27. Skehan P, Storeng R, Scudiero D, Monks A, McMahon J, Vistica D, Warren JT, Bokesch H, Kenney S, Boyd MR (1990) New colorimetric cytotoxicity assay for anticancer-drug screening. J Natl Cancer Inst 82:1107-1112

28. Mallinger A, Schiemann K, Rink C, Stieber F, Calderini M, Crumpler S, Stubbs M, Adeniji-Popoola O, Poeschke O, Busch M, Czodrowski P, Musil D, Schwarz D, Ortiz-Ruiz MJ, Schneider R, Thai C, Valenti M, de Haven Brandon A, Burke R, Workman P, Dale T, Wienke D, Clarke PA, Esdar C, Raynaud FI, Eccles SA, Rohdich F, Blagg J (2016) Discovery of potent, selective and orally bioavailable small-molecule modulators of the mediator complexassociated kinases CDK8 and CDK19. J Med Chem 59(3):1078-1101

29. Jones G, Willett GP, Glen RC, Leach AR, Taylor RJ (1997) Development and validation of agenetic algorithm for flexible docking. J Mol Biol 267:727-748 